\title{
Detecting the Function of Finance through History
} An Essay in Celebration of the Work of JoostJonker'

\author{
Christiaan van Bochove, Christopher L. Colvin, and Oscar Gelderblom
}

\author{
TSEG $18(3): 125^{-166}$ \\ DOI: $10.52024 /$ tseg. 11076
}

\begin{abstract}
This special review article profiles the work of Joost Jonker, who is retiring from his chair at the University of Amsterdam in 2021. We situate Joost's work in the international literature on the financing of governments, businesses, and households, showing how his contributions to the field of financial history influence and mirror wider trends. We focus on Joost's preferred methodology (the analytic narrative) and his preferred theoretical lens (the functional perspective). We conclude with a discussion of possible future developments in the field of financial history. Our intention is for this article to become a useful resource for new scholars entering the field of financial history, particularly on topics relating to the Low Countries.
\end{abstract}

1 We thank Joost's colleagues, collaborators, and friends for reading a draft of this article and contributing their ideas: Jan Annaert, Tijn van Beurden, Frans Blom, Corinne Boter, Bram Bouwens, Frans Buelens, Jonathan Conlin, Peter van Dam, Joost Dankers, Giuseppe Dari-Mattiaci, Ariëtte Dekker, Marc Deloof, Heidi Deneweth, Dave De ruysscher, Roger De Peuter, Amaury de Vicq, Jessica Dijkman, Hugo van Driel, Alberto Feenstra, Philip Fliers, Ton de Graaf, Bob de Graaff, Hilde Greefs, Leslie Hannah, Marjolein 't Hart, Laura van Hasselt, Jan Hoffenaar, Carmen Hofmann, Bram van Hofstraeten, Nico van Horn, Mark Hup, Abe de Jong, Herman de Jong, Matthijs de Jongh, James Kennedy, Hein Klemann, Heleen Kole, Peter Koudijs, Simon Lelieveldt, Bas Machielsen, Bram Mellink, Ranald Michie, Michael Milo, Anne Murphy, Larry Neal, Margreet de Nie-Sarink, Ruben Peeters, Lodewijk Petram, Jeroen Puttevils, Angelo Riva, Will Roberds, Faheem Rokadyha, Jean-Laurent Rosenthal, Wouter Ryckbosch, Co Seegers, Josje Schnitzeler, Keetie Sluyterman, John Turner, Tim van der Valk, Herman Van der Wee, Bouke Veldman, Marcia van Woensel, Jan Luiten van Zanden, and Jaco Zuijderduijn. We thank the $T S E G$ editorial team for supporting us. We take the blame for any omissions, of which we are sure there are many. 


\section{Introduction}

With this review article we mark Joost Jonker's retirement as the NEHA Professor of Business History at the University of Amsterdam, a position he has held since 2012. As his students, colleagues, and friends, we wish to highlight in one place the varied and voluminous contributions Joost has made to the field of financial history throughout his career. ${ }^{2}$ Yet we also wish to contextualize his work, to situate it within the wider renewal in financial history scholarship that has taken place across Joost's career. In so doing, we show how Joost's publications on Dutch financial history have both directly influenced, and have been influenced by, wider debates on the financing of governments, businesses, and households across history.

When Joost published his very first articles in 1988 on the emergence of small rural credit cooperatives in the southern part of the Netherlands, financial historians in Europe and North America had a clear yet also rather narrow research agenda. ${ }^{3}$ Their primary interest was in the rise of banks and stock exchanges as the harbingers of financial modernity and key sources of funding for capitalist enterprise. ${ }^{4}$ Most of their research dealt with the late nineteenth and early twentieth centuries. Those focussing on the pre-industrial period typically studied the alleged forerunners of modern financial institutions and organizations. ${ }^{5}$ This almost whiggish approach earned the Italian citystates and the Low Countries a special place in the pantheon of financial history, with their early examples of banks and joint-stock compa-

2 Aside from some references and the bibliography, this focus means Joost's wider contribution to the field of business history will remain underexposed.

3 J. Jonker, 'Welbegrepen eigenbelang. Ontstaan en werkwijze van boerenleenbanken in NoordBrabant, 1900-1920', Jaarboek voor de Geschiedenis van Bedrijf en Techniek 5 (1988) 188-207; J. Jonker, 'Boerenvreugde of boerenverdriet? De NCB en de emancipatie van het Brabantse platteland, 18961920', Tijdschrift voor Sociale Geschiedenis 14 (1988) 444-49o.

4 For literature on stock markets, see:J. Turner, 'Financial economics and financial history', in:Y. Cassis, R.S. Grossman and C. Schenk (eds.), Oxford handbook of banking and financial history (Oxford 2016). For literature on banks, see: C.L. Colvin, 'The past, present and future of banking history', in: J.F. Wilson et al., (eds.), The Routledge companion to business history (Abingdon 2017). For literature on stock markets and banks, see: C. Fohlin, 'Financial systems', in: C. Diebolt and M. Haupert (eds.), Handbook of cliometrics (Cham 2019) 945-982.

5 For a review, see: O. Gelderblom and F. Trivellato, 'The business history of the preindustrial world. Towards a comparative historical analysis', Business History 61:2 (2019) 225-259. Note that Douglass North and others writing in the New Institutional Economics tradition make a clear distinction between institutions (the rules of the game) and organizations (agents constrained by these rules). Financial historians, however, do not typically keep this distinction - probably because they are often difficult to disentangle. 
nies, in addition to their innovations in public debt management. The attention paid to the Low Countries' economic precociousness ensured they remained a popular subject of historical enquiry. Still, it is unclear whether this extra attention always yielded useful historical insights.

The somewhat narrow approach to the Netherlands was not just a problem with international scholarship in financial history. Rather than stepping back and looking at the evidence afresh, work by academics based in the Netherlands often just followed the latest fashion or amounted to little more than restatements of the prevailing dominant narratives. Almost all of it was written in Dutch for a domestic audience. Alongside others, Joost went about to change this status quo by carrying out the necessary archival spadework and setting aside preconceived ideas about the essential role of banks in financial systems. Indeed, in one of his polemical early contributions, written as a graduate student in 1991, Joost nailed his colours to the mast in a noholds-barred take-down of the state of the literature on the financing of Dutch industry. ${ }^{6}$ In this piece, published in a predecessor journal to $T S E G$, Joost set out what would essentially become his research agenda for the next three decades: reconsidering dominant ideas about the role of finance in Dutch history through the careful collection and interpretation of newly collected historical evidence.

Beyond his specific contributions to Dutch financial history, we will demonstrate how Joost has persistently been at the forefront of his field in his use of economic theory in a way that strengthens the historian's role as a detective. This position means using economics as a lens through which to piece together disparate archival evidence, rather than as pre-installed software that determines the identity and nature of the financial institutions under study. Joost's methodological contribution has been to show how historians can go about writing convincing causal stories about the societal function of finance, as well as demonstrate how stories that pertain to one specific time and place can be written as part of a global history of finance. ${ }^{7}$ Indeed, when placed

6 J. Jonker, 'Lachspiegel van de vooruitgang, het historiografische beeld van de Nederlandse industriefinanciering in de negentiende eeuw', NEHA-Bulletin 5 (1991) 5-23.

7 Obviously Joost was not the only one in financial history doing this. See, among others: A.M. Carlos and S. Nicholas. 'Giants of an earlier capitalism. The chartered trading companies as modern multinationals', The Business History Review 62:3 (1988) 398-419; L. Neal, The rise of financial capitalism. International capital markets in the age of reason (Cambridge 1990); N.R. Lamoreaux, Insider lending. Banks, personal connections, and economic development in industrial New England (Cambridge 1996); P.T. Hoffman, G. Postel-Vinay and J.-L. Rosenthal. Priceless markets. The political economy of credit in Paris, $1660-$ 1870 (Chicago 2000). 
alongside the work of his contemporaries, as we will do here, Joost's work shows how the same financing problems could be solved in myriad ways, with the help of a broad range of public and private, formal and informal institutions. Together, this body of work demonstrates convincingly that throughout history, households, businesses, and governments largely succeeded in having their financing demands met. Even so, the need to adapt to local conditions, (circum)navigate the institutions of the state, and accommodate arrangements inherited from previous eras, meant they often met this demand in quite different ways. $^{8}$

Thirty years have passed since Joost started contributing to financial history. The field has changed profoundly, both in the Netherlands and elsewhere. By force of greater international collaboration between scholars, their application of economic theory, their collection and digitization of new historical source material, and their nuanced comparative analyses across time and place, a new and much richer story is emerging. The well-known giants of early capitalism - be they chartered companies or universal banks - have been found to have much more complex histories and, at times, also carried considerable cost for society at large. ${ }^{9}$ At the same time, the literature has now unequivocally demonstrated there have always been alternative forms of finance, many of which persisted alongside banks and corporations. ${ }^{10}$ What is more, as we will see below, the many ways in which pre-modern and modern business owners, financiers, and public officials solved funding problems were usually tailored to specific local circumstances.

In this article we review Joost's scholarly work alongside that of his contemporaries to demonstrate how financial historians have been working towards a more comprehensive understanding of financial institutions past and present. We start by documenting how Gerschen-

8 See contributions to: D.J. Forsyth and D. Verdier (eds.), The origins of national financial systems. Alexander Gerschenkron reconsidered (Abingdon 2003), including by Joost. Other good examples of this genre are: R.K. Morck (ed.), A history of corporate governance around the world. Family business groups to professional managers (Chicago 2007); and C.W. Calomiris and S.H. Haber, Fragile by design. The political origins of banking crises and scarce credit (Princeton 2014).

9 See, e.g.: S. Ogilvie, “Whatever is, is right"? Economic institutions in pre-industrial Europe', The Economic History Review 60:4 (2007) 649-684; and C. Fohlin, Finance capitalism and Germany's rise to industrial power (Cambridge 2007).

10 N.R. Lamoreaux, D.M.G. Raff and P. Temin, 'Beyond markets and hierarchies. Toward a new synthesis of American business history', The American Historical Review 108:2 (2003) 404-433; R. Cull et al., 'Historical financing of small-and medium-size enterprises', Journal of Banking \& Finance 30:1 1 (2006) 3017-3042. T. Guinnane et al., 'Putting the corporation in its place', Enterprise \& Society 8:3 (2007) 687729 . 


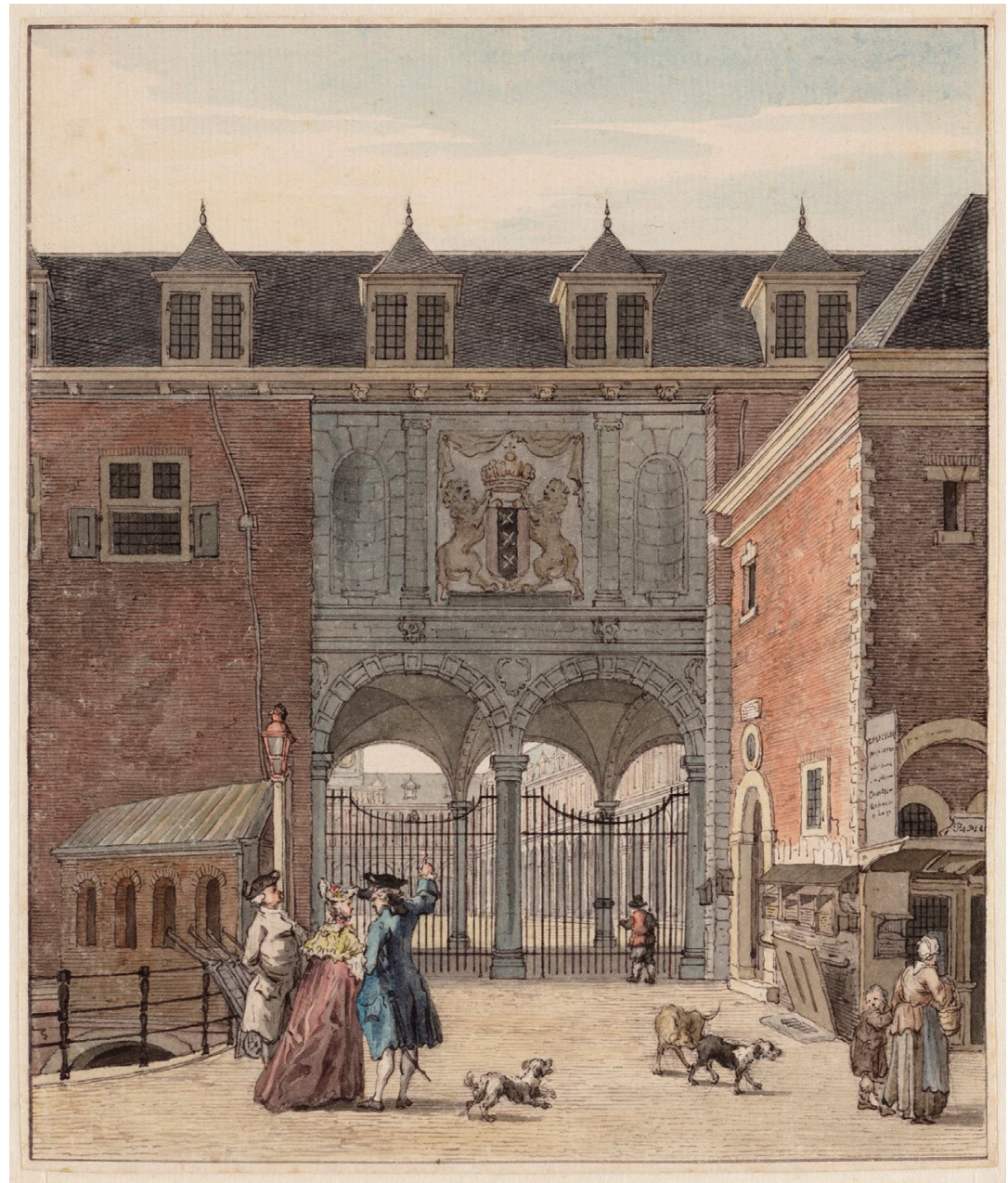

Illustration 1 This drawing, by Reinier Vinkeles (1768), captures the essence of Joost's research. It depicts the north entrance of the Amsterdam Exchange, a key location for classic financial historians. Also depicted, on the right-hand side, is a bookshop and stationers, where burghers could purchase all kinds of standardized and pre-printed contracts that allowed them to arrange financial transactions themselves. The drawing belongs to the Van Eeghen Collection, which Joost often uses in his research (source: Amsterdam City Archive, Collectie Van Eeghen: tekeningen, entry number 10055).

kron's ideas about the crucial role of banks in many industrializing countries came under attack in the 199 os as historians discovered other forms of business finance. Then we turn to the early modern period, where new work on both England's public finance and that of other countries has been chipping away at the triumphant story of the Glorious Revolution - or should we call it the Dutch Invasion? - paving the 
path to modern economic growth. Finally, we show how their empirical research, explicitly informed by economic theory, has allowed financial historians to write new narratives that are not only more convincing, but also have a wider usefulness beyond our field.

\section{Moving beyond Gerschenkron}

When Joost entered the field of financial history, the work of Alexander Gerschenkron (and Rondo Cameron) led the research agenda into the history of banking. ${ }^{11} \mathrm{He}$ postulated that during the late nineteenth century all industrializing countries - with the exception of England, the first mover, where retained earnings and funds from family and friends still sufficed - relied on banks to finance the new forms of economic activity. He argued full-service 'universal banks' acted as the key financial and entrepreneurial institutions that facilitated industrialization in countries - particularly Germany - that had missed the Industrial Revolution. The superiority of Germany's industrial economy was offered as proof that this institutional arrangement was best. Meanwhile, in a foreshadowing of Douglass North's New Institutional Economics, the argument went that where societies were too backward for banks to emerge spontaneously, their role could be taken up by other substitute institutions - such as the state in the case of Imperial Russia.

This narrative presented a simple but appealing proposition to historians across the Western world for studying the development of banking from the nineteenth century onwards. ${ }^{12}$ Joost was one of them. As an undergraduate, he started working on the early history of rural credit cooperatives, which led to a job as a research assistant at De Nederlandsche Bank, documenting the interaction between banks and industry in the early twentieth century, and the effect this interplay had on bank failures

11 A. Gerschenkron, Economic backwardness in historical perspective. A book of essays (Cambridge MA 1962); R. Cameron (ed.), Banking in the early stages of industrialization. A study in comparative economic history (New York 1967).

12 See, e.g.: R. Sylla, 'Federal policy, banking market structure, and capital mobilization in the United States, 1863-1913', The Journal of Economic History 29:4 (1969) 657-686; A.D. Chandler Jr., Scale and scope. The dynamics of industrial capitalism (Cambridge MA 199o); R. Sylla and G. Toniolo (eds.), Patterns of European industrialization. The nineteenth century (London 1991); M. Collins, 'English bank development within a European context, 1870-1939', The Economic History Review 51:1 (1998) 1-24; C. Fohlin, 'The balancing act of German universal banks and English deposit banks, 1880-1913', Business History 43:1 (2001) 1-24. 
in the early $1920{ }^{13}{ }^{13}$ Then followed a single-authored monograph on the merchant bank of Mees Pierson - a commissioned work on the occasion of the bank's $275^{\text {th }}$ anniversary. ${ }^{14}$ Yet Joost's findings were at odds with the optimistic beliefs about the role of banks. The members of rural credit cooperatives used their banks to save money, not to borrow; newly established banks were very susceptible to failure; and, most importantly, bank loans were but one of many sources of finance for the rapidly expanding Dutch industry. It made Joost realize that by looking from the vantage point of just the surviving institutions, financial historians could not really tell how business owners actually funded their firms.

Joost was not the only financial historian to question the old Gerschenkron-Cameron paradigm. In the US, one strand of the literature continued to emphasize that the creation of a sound system of public finance and a thriving stock market were instrumental to economic growth. ${ }^{15}$ In another strand, however, research by Naomi Lamoreaux, Howard Bodenhorn, and Robert Wright explored how the financing of business worked 'from the ground up'. They found early US banking was grafted onto the personal relations between bankers and the business owners to whom they provided funding. While these financial institutions labelled themselves 'banks', they behaved very differently from what the traditional understanding of banks prescribed. They also found types of banks that not only supplied long-term capital but also short-term credit - the latter being crucial as many business owners worried more about liquidity than fixed investments. ${ }^{16}$

Meanwhile, in the case of Germany - Gerschenkron's 'patient zero' Caroline Fohlin as well as Sheilagh Ogilvie and Jeremy Edwards demonstrated universal banks were far less important than long thought. ${ }^{17}$

13 As a research assistant, Joost helped process the letters of central banker and minister of finance N.G. Pierson for a publication edited by Jacques van Maarsenveen (Briefwisseling van Nicolaas Gerard Pierson 1839-1909, Amsterdam, 1990-1993). He also carried out archival research for a monograph by Johan de Vries (De Nederlandsche Bank van 1914 tot 1948. Visserings tijdvak 1914-1931, Amsterdam 1994).

14 J. Jonker, MeesPierson. Schakel tussen verleden en toekomst. 275 jaar traditie en vernieuwing in het Nederlands bankwezen (Amsterdam 1997).

15 R. Sylla, 'Financial systems and economic modernization', The Journal of Economic History 62:2 (2002) 277-292.

16 Lamoreaux, Insider lending. H. Bodenhorn, A history of banking in antebellum America. Financial markets and economic development in an era of nation-building (New York 200o); R.E. Wright, The origins of commercial banking in America, 1750-1800 (London 2001).

17 J. Edwards and S. Ogilvie, 'Universal banks and German industrialization. A re-appraisal', The Economic History Review 49:3 (1994) 427-446; C. Fohlin, 'Universal banking in pre-World War I Germany. Model or myth?', Explorations in Economic History 36:4 (1999) 305-343. 
They likely had much less influence on the direction and speed of Germany's industrialization. At the same time, Timothy Guinnane directed attention to other forms of banking organization that emerged throughout the German lands: cooperatives. ${ }^{18}$ These small local banks were not meant to fund urban entrepreneurs but were instead geared to solving funding constraints in rural society. Making use of information theory from economics, Guinnane documented exactly how nineteenth-century credit cooperatives were able to build on existing social relations for screening and monitoring to secure new forms of credit to fund rural enterprise. Combined, these new works demonstrated that, at the local level, significant room existed for financial institutions that did not fit neatly into the banking straightjacket. ${ }^{19}$

Three French and American economic historians - Philip Hoffman, Gilles Postel-Vinay, and Jean-Laurent Rosenthal - took the debate an additional step forward through their work on French credit markets between the late seventeenth and early twentieth centuries. ${ }^{20}$ Their initial work revealed that when banks were still largely absent from French society, it did not mean French lenders and borrowers went without financial intermediaries. By closely analyzing the sources, they demonstrated how notaries broadened access to credit by matching demand and supply. They could do so because they were well-informed about wealth holders and because - in the absence of a lien registry - notaries were the sole record keepers of real estate transactions. ${ }^{21}$ The authors' later work showed the credit networks which notaries maintained persisted well into the nineteenth century. ${ }^{22}$ They endured not because there were no banks, but because notaries catered to a part of the credit market not (yet) served by banks; French notaries and banks were complementary.

18 T. Guinnane, 'Cooperatives as information machines. German rural credit cooperatives, ${ }^{188} 3^{-}$ 1914', The Journal of Economic History 61:2 (2001) 366-389.

19 F. Carnevali, Europe's advantage. Banks and small firms in Britain, France, Germany, and Italy since 1918 (Oxford 2005), also fits into this strand of the literature.

20 Hoffman, Postel-Vinay and Rosenthal, Priceless markets.

21 In the absence of a functional lien registry, scriveners and attorneys assumed a similar role in England. The literature on these professional writers is somewhat less developed, however, presumably because it could rely less on systematic, quantitative data and did not frame the activities of these intermediaries in terms of preconditions for economic development. See: C. van Bochove, H. Deneweth and J. Zuijderduijn, 'Real estate and mortgage finance in England and the Low Countries, 1300-180o', Continuity and Change 30:1 (2015) 9-38.

22 P.T. Hoffman, G. Postel-Vinay and J-L. Rosenthal, Darkmatter credit. The development of peer-to-peer lending and banking in France (Princeton 2019). 
Hoffman, Postel-Vinay, and Rosenthal opened up new ways of thinking about the organization of financial systems. For one thing, their work led scholars to explore the role of notaries as financial intermediaries in other countries. ${ }^{23}$ This research found that notaries in other parts of the world sometimes did, and sometimes did not, intermediate on credit markets. It has helped lay bare a much greater variety of non-bank financial intermediaries. This strand of literature was complemented by scholars focusing on other kinds of peer-to-peer lending; Craig Muldrew and Laurence Fontaine, as well as a wide range of scholars focussing on the survival strategies of the early modern poor, demonstrated the ubiquity of this lending technology. ${ }^{24}$ Clearly, then, the prevalence of many alternative sources of direct and indirect funding meant financial history should be much richer than just the rise of banks or joint-stock corporations. ${ }^{25}$

This potential was exactly what Joost envisaged when he was working on his $\mathrm{PhD}$ dissertation in the early 199 os. ${ }^{26}$ Unaware of the work Hoffman and others were doing at that very moment, Joost conducted equally meticulous primary research to reconstruct the functioning of Amsterdam's financial market in the first half of the nineteenth century. Joost framed his doctoral research as a reckoning with the alleged backwardness of the Dutch economy in the first half of the nineteenth century, but his contribution was more fundamental. ${ }^{27}$ Joost followed

23 See, among others: J. Levy, The making of a market. Credit, henequen, and notaries in Yucatán, $1850-$ 1900 (University Park 2012), and the contributions and references in: M. Lorenzini, C. Lorandini and D'M. Coffman (eds.), Financing in Europe. Evolution, coexistence and complementarity of lending practices from the Middle Ages to modern times (Cham 2018).

24 C. Muldrew, The economy of obligation. The culture of credit and social relations in early modern England (Basingstoke 1998); L. Fontaine, The moral economy. Poverty, credit, and trust in early modern Europe (Cambridge 2014).

25 A.E.C. McCants, 'Goods at pawn. The overlapping worlds of material possessions and family finance in early modern Amsterdam', Social Science History 31:2 (2007) 213-238; T. Lambrecht and P. Schofield (eds.), Credit and the rural economy in North-Western Europe, c.1200-c.1850 (Turnhout 2009); D. Vickers, 'Errors expected. The culture of credit in rural New England, 1750-1800', The Economic History Review $63: 4$ (2010) 1032-1057; S. Ogilvie, M. Küpker and J. Maegraith, 'Household debt in early modern Germany. Evidence from personal inventories', The Journal of Economic History $72: 1$ (2012) 134-167; J.L. van Zanden, J. Zuijderduijn and T. de Moor, 'Small is beautiful. The efficiency of credit markets in the late medieval Holland', European Review of Economic History 16:1 (2012) 3-22; C. van Bochove and H. Kole, 'Uncovering private credit markets. Amsterdam, 166o-18o9', Tijdschrift voor Sociale en Economische Geschiedenis 11:3 (2014) 39-72; C. Milhaud, 'Interregional flows of capital and information in Spain. A case study of the Theresian Carmelite order', Revista de Historia Económica 37:1 (2019) 81-110; E.M. Dermineur, 'Peer-to-peer lending in pre-industrial France', Financial History Review 26:3 (2019) 359-388.

26 J. Jonker, Merchants, bankers, middlemen. The Amsterdam money market during the first half of the 19th century (Amsterdam 1996).

27 J.A. de Jonge, De industrialisatie in Nederland tussen 1850 en 1914 (Amsterdam 1968); J. Mokyr, Industrialization in the Low Countries, 1 795-1850 (New Haven 1976); R.T. Griffiths, Industrial retardation 
up his thesis with a paper very explicitly framed as a reconsideration of the Gerschenkron thesis for the Dutch case. ${ }^{28}$ Just like studies on the US, Germany, and France, the Dutch case shows banks offer but one of several ways to secure funding for business enterprise. At the same time Joost demonstrated that equity and debt markets were not just functional substitutes but, rather, developed in tandem, with stocks and bonds used as collateral for loans - an observation that would play an important role in his later work on finance in the Dutch Republic. ${ }^{29}$

In retrospect, Joost's dissertation thus unmistakably belongs to a much wider literature of thorough research into the funding of businesses and households based on (non-bank) sources. Over the course of Joost's career the paradigm has fundamentally shifted, however. No longer is the most exciting research primarily dedicated towards tracing the roots of financial institutions - such as banks - that came to play an important role in the financial system of the twentieth century. Instead, a new school of research has taken a more hands-on approach to 'follow the money' and see how business was actually financed, from the ground up. Besides addressing who the key players were, this method also meant paying attention to the instruments and strategies that were used, assessing how successful these were, and trying to understand what caused change over time and difference across space. It does not mean that universal banks can no longer be the subject of academic enquiry but, rather, that their study can now be decoupled from Gerschenkron's narrative and explored in the context of other questions. ${ }^{30}$ Indeed, understanding the origins, function, and evolution of full-service banking organizations and their leaders in the Dutch case

in the Netherlands, $1830-1850$ (The Hague 1979); M. Jansen, De industriële ontwikkeling in Nederland 1800-1 850 (Amsterdam 1999); M. Janse, De geest van Jan Salie. Nederland in verval? (Hilversum 2002). 28 J. Jonker, 'Competing in tandem. Securities markets and commercial banking patterns in Europe during the nineteenth century', in: Forsyth and Verdier (eds.), The origins, 80-102.

29 See: S. van Nieuwerburgh, F. Buelens and L. Cuyvers, 'Stock market development and economic growth in Belgium', Explorations in Economic History 43:1 (2006) 13-38, for the importance of stock markets in funding industry in neighbouring Belgium.

30 For examples of this renewed research agenda in the Dutch case, see: T. de Graaf, Voor handel en maatschappij. Geschiedenis van de Nederlandsche Handel-Maatschappij, 1824-1964 (Amsterdam 2012); G. Westerhuis and A. de Jong, Over geld en macht. Financiering en corporate governance van het Nederlandse bedrijfsleven (Amsterdam 2015); L. Petram, Devergeten bankencrisis (Amsterdam 2016); A. de Jong, P. Fliers and H. van Beusichem, 'Catering and dividend policy. Evidence from the Netherlands over the twentieth century', Financial History Review 26:3 (2019) 321-358. For the case of neighbouring Belgium, see: W. van Overfelt et al., 'Do universal banks create value? Universal bank affiliation and company performance in Belgium, 1905-1909', Explorations in Economic History 46:2 (2009) 253-265. 


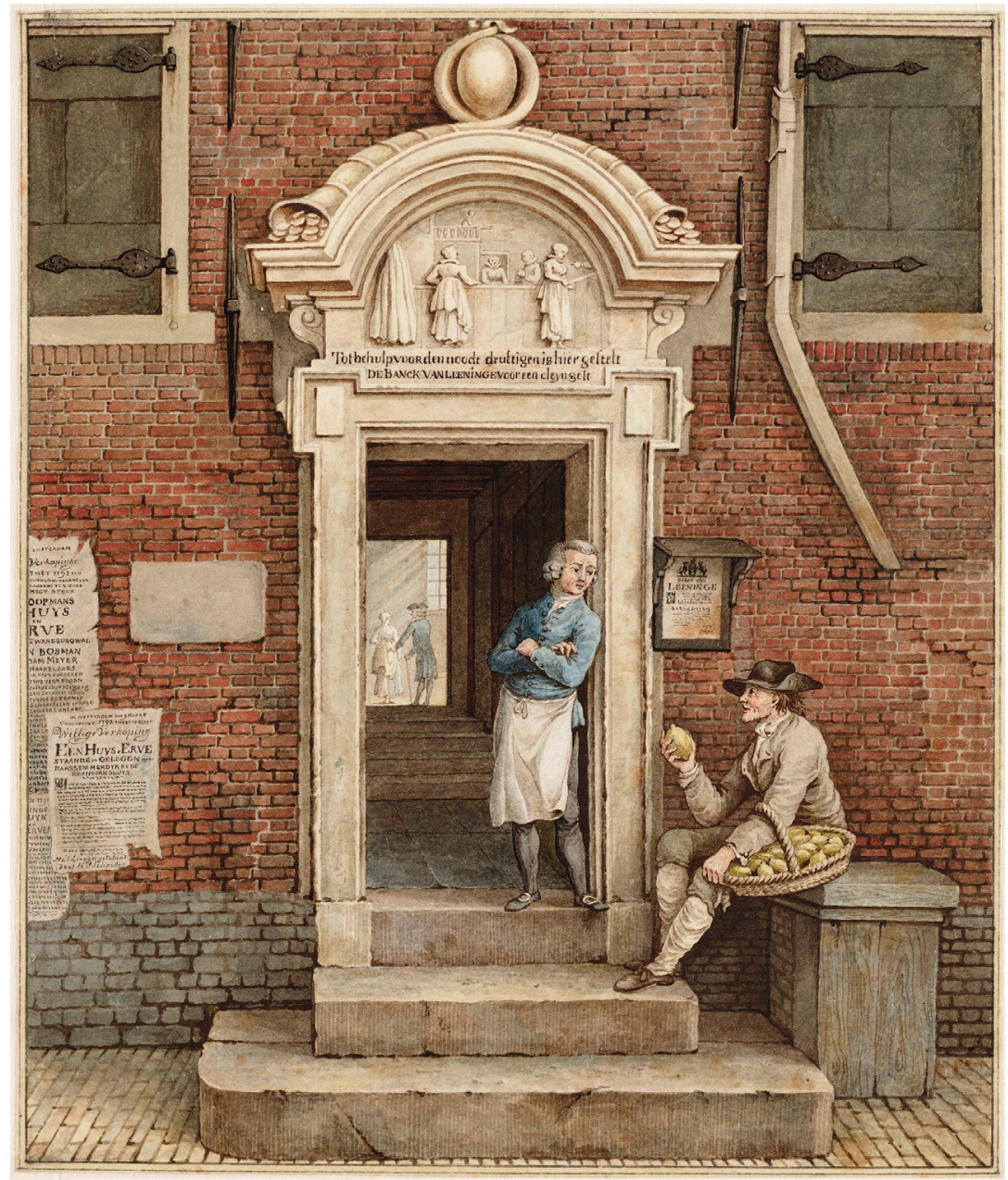

Illustration 2 This drawing, by Herman Schouten (1792), depicts the entrance of Amsterdam's municipal pawnshop: the Bank van Lening. The tranquillity suggested by this drawing is misleading because this institution provided hundreds of loans to ordinary burghers, on a daily basis. Rather than focusing on the largest and most prominent institutions, Joost's research approach has been to look at how households and small businesses actually used pawn credit. He found many more small pawn loans were raised on a peer-to-peer basis and in Amsterdam's less visible private pawnshops (source: Amsterdam City Archive, Collectie Atlas Splitgerber, entry number 10001).

has proved a fruitful research topic for some of Joost's own graduate students and mentees. ${ }^{31}$

31 C.L. Colvin, 'Interlocking directorates and conflicts of interest. The Rotterdamsche Bankvereeniging, Müller \& Co. and the Dutch financial crisis of the 1920s', Business History 56:2 (2013) 314-334; C.L. Colvin, A. de Jong and P. Fliers, 'Predicting the past. Understanding the causes of bank distress in the Netherlands in the 1920s', Explorations in Economic History 55 (2015) 97-121; A.P. Dekker, Leven op 


\section{Moving beyond North and Weingast}

Meanwhile, there was one country where financial history research was hardly influenced by the debunking of the Gerschenkron thesis: England. After all, England did not feature directly in Gerschenkron's narrative of industrialization; in explaining how industrial laggards caught up with the world's first industrial nation, he was concerned only with England as a reference ${ }^{32}$ Instead, financial historians of the British Isles were concerned with other things: understanding London's emergence as the world's financial centre by importing and adapting institutions from the Low Countries; ${ }^{33}$ its functioning as an international market for bullion, trade credit, private stocks, and state loans; ${ }^{34}$ its use of retained earnings rather than bank loans to fuel the Industrial Revolution; ${ }^{35}$ and tracking the emergence of England's system of country and provincial banks..$^{36}$ To some extent, the UK's financial historians were much more concerned with writing new monetary histories, responding to the work of Friedman and Schwartz. ${ }^{37}$ Work on free banking in Scotland can also be seen in this light, where researchers remained fascinated by the 'absence' of the state in organizing the financial system and the medium of exchange. ${ }^{8}$ Together, these strands of literature

krediet. Anton Kröller (1862-1941) (Groningen/Amsterdam 2015); A. de Vicq, 'Exploring the limits of the limited partnership. The case of the Bank of Twente, 186os-1920s', Enterprise \& Society (2021) 1-26. 32 It is not, of course, entirely correct to argue that Gerschenkron's thesis had no influence. Certainly it inspired work on the role of banks in England's relative industrial decline during the Second Industrial Revolution. See, especially: F.H. Capie and T.C. Mills, 'British bank conservatism in the late 19 th century', Explorations in Economic History 32:3 (1995) 409-420.

33 P. Spufford, 'From Antwerp and Amsterdam to London. The decline of financial centres in Europe', De Economist 154 (2006) 143-175; L. Neal, 'How it all began. The monetary and financial architecture of Europe during the first global capital markets, 1648-1815', Financial History Review 7:2 (2000) 117-140; A.M. Carlos and L. Neal, 'Amsterdam and London as financial centers in the eighteenth century', Financial History Review 18:11 (2011) 21-46.

34 Neal, The rise; R. Michie, The City of London, continuity and change 1850-1990 (London 1992); Idem, The London stock exchange. A history (Oxford 2001).

35 L. Neal, 'The finance of business during the industrial revolution', in: R. Floud and D. McCloskey (eds.), The economic history of Britain since 1 700 I: 1700-1860 (Cambridge 1994) 151-181.

36 L.S. Pressnell, Country banking in the Industrial Revolution (Oxford 1956); P.R. Cottrell, Industrial finance. The finance and organization of English manufacturing industry (London 1980); L. Newton, 'Regional bank-industry relations during the mid-nineteenth century. Links between bankers and manufacturing in Sheffield, c.1850 to c.1885', Business History $38: 3$ (1996) 64-83.

37 M. Friedman and A.J. Schwartz, A monetary history of the United States, 1867-1960 (Princeton 1963); F.H. Capie and A. Webber, A monetary history of the United Kingdom, $1870-1982$ (London 1985). 38 L. White, Free banking in Britain. Theory, experience and debate, $1800-1845$ (New York 1984); C.R. Hickson and J.D. Turner, 'Free banking and the stability of early joint-stock banking', Cambridge Journal of Economics 28:6 (2004) 903-919. 
already showed there were many ways in which finance could be arranged; there was never a single monolithic view on the banking/industrialization nexus.

And yet, the English case once more shackled financial history research through another very influential but empirically unsustainable generalization. In 1989 The Journal of Economic History published an article by Douglass North and Barry Weingast about the early modern origins of the Industrial Revolution. The puzzle they tried to solve is well known. How did a country whose economy was eclipsed by that of the Dutch Republic, and whose political system completely collapsed in the mid-seventeenth century, manage to realize major innovations in agriculture, industry, and finance during the eighteenth century, which then turned it into the world's first truly global superpower? ${ }^{39}$

The answer North and Weingast offered was appealing because of its straightforwardness. The Glorious Revolution brought the Dutch stadhouder, Willem III - who was married to Mary, the Protestant daughter of the deposed Catholic king, James II - to the English throne. To facilitate this transfer of power, Willem made far-reaching concessions to Parliament. While he continued to decide on waging war, Parliament obtained full control over the nation's purse. This authority included a final say over which and how much tax could be levied. According to North and Weingast, this control represented nothing less than a 'Financial Revolution', because Parliament's enhanced powers provided a mechanism for the king to credibly commit to repaying his lenders, that is: the very people - and their families - who held seats in Parliament. With lenders essentially in the driver's seat - and property rights more secure than ever before - it became much easier to raise public debt at low costs. Through the property rights channel, the Financial Revolution spilled over into private credit markets, increasing investments and, hence, stimulating economic growth.

North and Weingast's article became one of the most influential papers in the field of economic history. Not because they had discovered England's Financial Revolution - Peter Dickson had already done so during the $196 \mathrm{os}^{40}$ - but because they connected po- 
litical and economic development. During the 1980s, when capitalism seemed triumphant around the world and the governments of the US and UK cleared the way for private investors and business enterprise through extensive deregulation of the financial sector, their simple message resonated among economists. Two years after his article with Weingast appeared in print, Douglass North was awarded the Nobel Memorial Prize for exactly this type of research: how the formal and informal rules of the game determine economic outcomes. $^{41}$

The ensuing scholarly debate very much resembled the one that Gerschenkron's ideas had triggered. Those inspired by it used North and Weingast's article as the key reference point and found earlier financial revolutions in the medieval city-states of Italy, the Dutch Republic during the sixteenth and seventeenth centuries, or in the US and Japan during the eighteenth and nineteenth centuries..$^{42}$ North and Weingast's double bargain over taxes and loans played out differently in different contexts, depending on the relative strengths of local elites and their ease of access to foreign and domestic capital. Hence, scholars investigating this relationship have found very different configurations across time and space. ${ }^{43}$

The North-Weingast thesis quickly attracted critics. Long-term and comparative research into interest rate behaviour by Gregory Clark, Stephen Quinn, and Larry Epstein showed public and private interest rates had been declining in England for a much longer period without fundamental changes in its political regime. ${ }^{44}$ They had also declined

1688-1 756 (London 1967); J. Brewer, The sinews of power. War, money and the English state, 1688-1 783 (London 1989).

41 D.C. North, 'Economic performance through time', Prize Lecture, The Sveriges Riksbank Prize in Economic Sciences in Memory of Alfred Nobel 1993 (9 December 1993).

42 Sylla, 'Financial systems', 277-292; P.L. Rousseau and R. Sylla, 'Financial systems, economic growth, and globalization', in: M.D. Bordo, A.M. Taylor and J.G. Williamson (eds.), Globalization in historical perspective (Chicago 2003) 373-416.

43 F.R. Velde and D.R. Weir, 'The financial market and government debt policy in France, 1746-1793', The Journal of Economic History 52:1 (1992) 1-39; C. van Bochove, 'External debt and commitment mechanisms. Danish borrowing in Holland, 1763-1825', The Economic History Review 67:3 (2014) 652677; M. Drelichman and H.-J. Voth, Lending to the borrower from hell. Debt, taxes, and default in the age of Philip II (Princeton 2014); Idem, 'Duplication without constraints. Álvarez-Nogal and Chamley's analysis of debt policy under Philip II', The Economic History Review 69:3 (2016) 999-10o6; C. Álvarez-Nogal and C.P. Chamley, 'Response to "Duplications" by Drelichman and Voth', The Economic History Review 69:3 (2016) 1007-1013.

44 G. Clark, 'The political foundations of modern economic growth. England, 1540-180o', Journal of Interdisciplinary History 26 (1996) 563-588; S.R. Epstein, Freedom and growth. The rise of states and markets in Europe, 1300-1 750 (London 2000); S. Quinn, 'The Glorious Revolution's effect on English pri- 
- and were sometimes even lower - in other republican regimes, as well as in absolutist ones. ${ }^{45}$ Research into the fiscal capacity of states revealed that state size and fiscal centralization were key to successful state finances, ${ }^{46}$ as were the role of cities $^{47}$ and access to foreign financiers. ${ }^{48}$ Meanwhile, the English case gradually unravelled as historians realized that state borrowing may actually have retarded economic development, ${ }^{49}$ and that much of the success relied on debt-equity swaps with the large chartered companies - the Bank of England, the East India Company, and the South Sea Company - that investors trusted much more than the state. ${ }^{\circ}$ Eventually, Gary Cox demonstrated credible commitment operated through more complex political channels than North and Weingast had argued..$^{5^{1}}$ This type of revisionist work made North and Weingast's causal relationship between political regime change and economic development more tenuous.

This entire discussion is conspicuously absent from Joost's work in the 199os. Though he did follow British financial history research very closely, he took his inspiration from the work of Ranald Michie and Larry Neal instead. They found for London what Joost also observed in Amsterdam: stock markets were substitutes for banks and vice versa; there existed a constant interaction between the two, both locally and across space. This idea is at the heart of Joost's first endeavour into early modern history: his joint work with Keetie Sluyterman on the history of Dutch merchant houses. Comparing Amsterdam's role in internation-

vate finance. A microhistory, 1680-1 705', The Journal of Economic History 61:3 (2001) 593-615; N. Sussman and Y. Yafeh, 'Institutional reforms, financial development and sovereign debt. Britain 169o-179o', The Journal of Economic History 66:4 (2006) 9o6-935.

45 P. Schmelzing, 'Eight centuries of global real interest rates, R-G, and the "suprasecular" decline, 1311-2018', Bank of England Staff Working Paper 845 (2020).

46 R. Bonney (ed.), Economic systems and state finance (Oxford 1995); R. Bonney (ed.), The rise of the fiscal state in Europe, c.1200-1815 (Oxford 1999); M. Dincecco, Political transformations and public finances. Europe, 1650-1913 (Cambridge 2011).

47 D. Stasavage, States of credit. Size, power, and the development of European polities (Princeton 2011 ).

48 Drelichman and Voth, Lending; Van Bochove, 'External debt'.

49 P. Temin and H.-J. Voth, Prometheus shackled. Goldsmith banks and England's financial revolution after 1700 (Oxford 2013).

50 S. Quinn, 'Securitization of sovereign debt. Corporations as a sovereign debt restructuring mechanism in Britain, 1694-1750', SSRN Working Paper (March 2008).

51 G.W. Cox, 'War, moral hazard, and ministerial responsibility. England after the Glorious Revolution', The Journal of Economic History 71:1 (2011) 133-161; Idem, 'Was the Glorious Revolution a constitutional watershed?', The Journal of Economic History 72:3 (2012) 567-6oo; A.L. Murphy, 'Demanding “credible commitment". Public reactions to the failures of the early financial revolution', The Economic History Review 66:1 (2013) 178-197; D'M. Coffman, A. Leonard and L. Neal (eds.), Questioning credible commitment. Perspectives on the rise of financial capitalism (Cambridge 2013). 
al trade and finance with that of Antwerp and London, At Home on the World Markets (2001) demonstrates how versatile financial systems are in their ability to adapt to changing domestic and foreign demand for their services. The book's narrative, descriptive approach might seem old-fashioned compared to the new institutional analysis that was quickly gaining ground at the time. However, the careful and critical reconstruction of the functioning of the financial system of the Dutch Republic by Joost and others in the following two decades would demonstrate England's specific trajectory did not constitute the only or even the most efficient path to financial modernity. ${ }^{52}$

First of all, the Dutch case underscores the importance of fiscal change as a driving force in the modernization of public finance. Already in 1985, James Tracy had shown how, in the first half of the sixteenth century, a combination of tax reforms and the sales of annuities set the province of Holland on a trajectory very similar to the financial revolution Dickson described for England in the late seventeenth century. ${ }^{53}$ First Marjolein 't Hart, and then Wantje Fritschy, went on to show how the use of indirect taxes and the delegation of fiscal control from individual cities to the province allowed the Dutch to gain their independence from the Habsburg Empire. In subsequent work on the public finances of each of the Seven Provinces, Fritschy and her team minutely documented how ingenious Dutch fiscal authorities were in designing and resigning fiscal instruments. ${ }^{54}$ Jan de Vries's recent book on the price of bread showed how sophisticated and finely tuned the taxation of life's necessities actually became. ${ }^{55}$

52 Joost's work displays the same empirical rigour and conceptual clarity as that of an earlier generation of outstanding Flemish early modernists like Herman Van der Wee and Hugo Soly. See: H. Van der Wee, 'Anvers et les innovations de la technique financière aux XVIe et XVIIe siècles', Annales. Histoire, Sciences Sociales 22:5 (1967) 1067-1089; H. Soly, Urbanisme en kapitalisme te Antwerpen in de $16 d e$ eeuw. De stedebouwkundige en industriële ondernemingen van Gilbert van Schoonbeke (Brussel 1977).

53 J.D. Tracy, A financial revolution in the Habsburg Netherlands. Renten and renteniers in the county of Holland, 1515-1565 (Berkeley 1985); Cf. also: C.J. Zuijderduijn, Medieval capital markets. Markets for renten, state formation and private investment in Holland (1300-1550) (Leiden 2009).

54 M.C. 't Hart, The making of a bourgeois state. War, politics, and finance during the Dutch Revolt (Manchester 1993); W. Fritschy et al., 'Gewestelijke financiën ten tijde van de Republiek der Verenigde Nederlanden 1572-1795', Rijksgeschiedkundige Publicatiën 7 volumes (The Hague 1996-20o9); W. Fritschy, 'A "financial revolution" reconsidered. Public finance in Holland during the Dutch Revolt, 1568-1648', The Economic History Review 56:1 (2003) 57-89. Cf. for the interplay between fiscal policy and government borrowing: H.A. Feenstra, Between shared and conflicting interests. The political economy of the markets for public debt in the Dutch Republic, 1600-1 795, unpublished PhD dissertation (University of Amsterdam 2018). 55 J. de Vries, The price of bread. Regulating the market in the Dutch Republic (Cambridge 2019). 
Second, the Dutch case belies the idea that all it takes for financial revolutions to occur is the 'right' set of institutions. The financial prowess of the Dutch Republic was not just a matter of its peculiar governance structure and the ability of the maritime provinces to raise very high taxes. The Dutch benefited, moreover, from the growing riches of their population in another way, as Joost demonstrated in a joint article with Oscar Gelderblom. ${ }^{6}$ This article, on public finance in the late sixteenth and early seventeenth centuries, shifted attention from constraints on the ruler and sufficient fiscal revenues to economic growth and the interplay with investors. Economic growth not only drove up tax revenues, after all, but also resulted in rapidly accumulating capital looking for investment opportunities. ${ }^{57}$ That the state succeeded in directing these funds to the public debt in large part relied on the fact that it - and then especially the province of Holland - cleverly responded to investor preferences. A finely meshed network of local offices enabled investors to purchase public debt, collect interest payments, and get redeemed close to home..$^{58}$ In addition, the state issued instruments and set loan terms in response to market preferences, which even allowed it to attract investments from new segments of society - for example, through more speculative lottery loans.

Third, the Dutch case refutes the idea that political regime changes alone set in motion a virtuous cycle of financial innovations. Yes, throughout the sixteenth century major changes occurred in the balance of power between local and central government. ${ }^{59}$ It was not until the creation of the Vereenigde Nederlandsche Oost Indische Compagnie (VOC, or Dutch East India Company) in 1602, however, that securities markets matured enough to impact the real economy. Merchants quickly discovered the VOC's liquid shares were ideal collateral for loans. This repo market - for whose nineteenth-century equivalent Joost already demonstrated its centrality to business financing in his

56 O. Gelderblom and J. Jonker, 'Public finance and economic growth. The case of Holland in the seventeenth century', The Journal of Economic History 71:1 (2011) 1-39.

57 On the accumulation of wealth in the Dutch Republic: L. Soltow and J.L. van Zanden, Income and wealth inequality in the Netherlands, $16^{\text {th }}-20^{\text {th }}$ century (Amsterdam 1998).

58 M. van der Heijden, Geldschieters van de stad. Financiële relaties tussen stad, burgers, en overheden (Amsterdam 2006); M. 't Hart, 'Mutual advantages. State bankers as brokers between the city of Amsterdam and the Dutch Republic', in: O. Gelderblom (ed.), The political economy of the Dutch Republic (Farnham 2009) 115-142; C. van Bochove, 'Configuring financial markets in preindustrial Europe', The Journal of Economic History 73:1 (2013) 247-278; P. Brandon, War, capital, and the Dutch State (1588-1 795) (Leiden 2015).

59 Tracy, A financial revolution; Zuijderduijn, Medieval capital markets. 
dissertation - became so important that the interest rates which were set on it had to be considered by the States General in its own borrowing. ${ }^{60}$ In the eighteenth century, the economy once again took precedence as merchant houses central to (payments in) international trade ventured into acceptance credit, mortgage-backed securities, and lending to foreign sovereigns. ${ }^{61}$

It is this understanding of the interaction between public and private institutions that characterizes Joost's work on early modern society. By looking at the financial system as a whole - at the full range of instruments and intermediaries used by governments, businesses, and households to meet their financial demands - Joost and his co-authors were able to show how the public/private interactions presumed by institutional economists actually took shape. Again, the early history of the VOC is a prime example. The Dutch desire to enter the Asian trade and beat the Spanish led to the creation of a new kind of corporation that combined elements of the Roman law partnership, the joint ownership of merchant and fishing vessels (partenrederij), with the organization model of the admiralty boards already used in the navy. ${ }^{62}$ Indeed, the new company was a combination of contracts: a monopoly charter for 21 years combined with a ten years' capital account that would be liquidated in 1612, after which a new round of share subscriptions would follow. Yet the latter never happened.

To meet the demand for liquidity of the initial investors, the charter set clear and simple rules for the transfer of shares. This move did not just create a thriving stock market with allied credit techniques. ${ }^{6}{ }^{6}$ With investors now in a position to opt out at any time, the company directors decided to step up the company's military efforts in Asia; already in 1607 , they contemplated the indefinite continuation of the first ten years' account. This measure inspired two further innovations. Differ-

6o O. Gelderblom and J. Jonker, 'Completing a financial revolution. The finance of the Dutch East India trade and the rise of the Amsterdam capital market, 1595-1612', The Journal of Economic History 64:3 (2004) 641-672. Also see: P. Koudijs and H.-J. Voth, 'Leverage and beliefs. Personal experience and risk-taking in margin lending', The American Economic Review 106:1 1 (2016) 3367-340o.

61 J. Jonker and K. Sluyterman, At home on the world markets. Dutch international trading companies from the 16 th century until the present (The Hague 2000); J. Jonker, 'Klem tussen de lokale en mondiale markt, de Amsterdamse Haute Banque vanaf het midden van de zestiende tot het begin van de twintigste eeuw: Part I, 1550-1763', Amstelodamum 106:1 (2019) 25-45; 'Part II, 1763-1914', Amstelodamum 106:2 (2019) 63-87.

62 O. Gelderblom, A. de Jong and J. Jonker, 'An admiralty for Asia. Business organization and the evolution of corporate governance in the Dutch Republic, 1590-1640', in:J. Koppell (ed.), Origins of shareholder advocacy (New York 2011) 29-6o.

63 On the early stock market: L. Petram, The world's first stock exchange (New York 2014). 
ing expectations about the VOC's next moves led to forward trading among private investors, while the board of directors started talks with the States General to obtain permission to continue the first ten years' account to effectively create a permanent concern. ${ }^{64}$ And so they did in 1612, allowing the Dutch company to push ahead of its English East India Company rival, which failed to obtain any capital lock-in until much later. ${ }^{65}$ It was a crucial move to achieve the VOC's dual military and commercial goals, but in 1616 there was no money to pay the dividends the directors had promised in exchange for permanence. Shareholders were forced to accept company bonds instead, and while the renewal of the VOC charter in 1623 came with a promise to institute a committee of shareholders to oversee the directors' operations, an effective twotier system of control remained a dead letter. ${ }^{66}$ Indeed, the full potential of a corporate form with effective shareholder control would only be achieved in England in the second half of the seventeenth century. ${ }^{67}$

There is a final lesson to be learnt from something else that never happened in Dutch financial history: the financial crisis of 1720 . The Mississippi (France) and South Sea (England) bubbles have attracted a lot of scholarly attention from financial economists because they are early and appealing examples of asset price bubbles, and because excellent data enabled them to show for the first time that asset price bubbles were not a modern phenomenon per se. While Dutch investors no doubt helped to fuel the booms in Paris and London, similar bubbles were absent in the Dutch Republic. The reasons for this were that the Dutch state did not need these forms of finance to attract investors, and nearly all economically viable ventures had already been funded in the Dutch Republic. Although dozens of spectacular companies were in fact proposed, these were largely ignored by investors who understood perfectly well their speculative character. ${ }^{68}$

64 On forward trading: O. Gelderblom and J. Jonker, 'Amsterdam as the cradle of modern futures and options trading, 1550-1650', in:W.N. Goetzmann and K.G. Rouwenhorst (eds.), The origins of value. The financial innovations that created modern capital markets (Oxford 2005) 189-205.

65 O. Gelderblom, A. de Jong and J. Jonker, 'The formative years of the modern corporation. The Dutch East India Company VOC, 16o2-1623', The Journal of Economic History 73:4 (2013) 1050-1076; G. DariMattiacci et al., 'The emergence of the corporate form', Journal of Law, Economics, \& Organization 33:2 (2017) 193-236.

66 Gelderblom et al., 'Formative years'; M. de Jongh, Tussen societas en universitas. De beursvennootschap en haar aandeelhouders in historisch perspectief, unpublished $\mathrm{PhD}$ dissertation (Erasmus University Rotterdam 2014) 128-129.

67 Dari-Mattiacci et al., 'The emergence'; R. Harris, Going the distance. Eurasian trade and the rise of the business corporation, 1400-1700 (Princeton 2020).

68 O. Gelderblom and J. Jonker, 'Mirroring different follies, the character of the 1720 bubble in the Dutch 


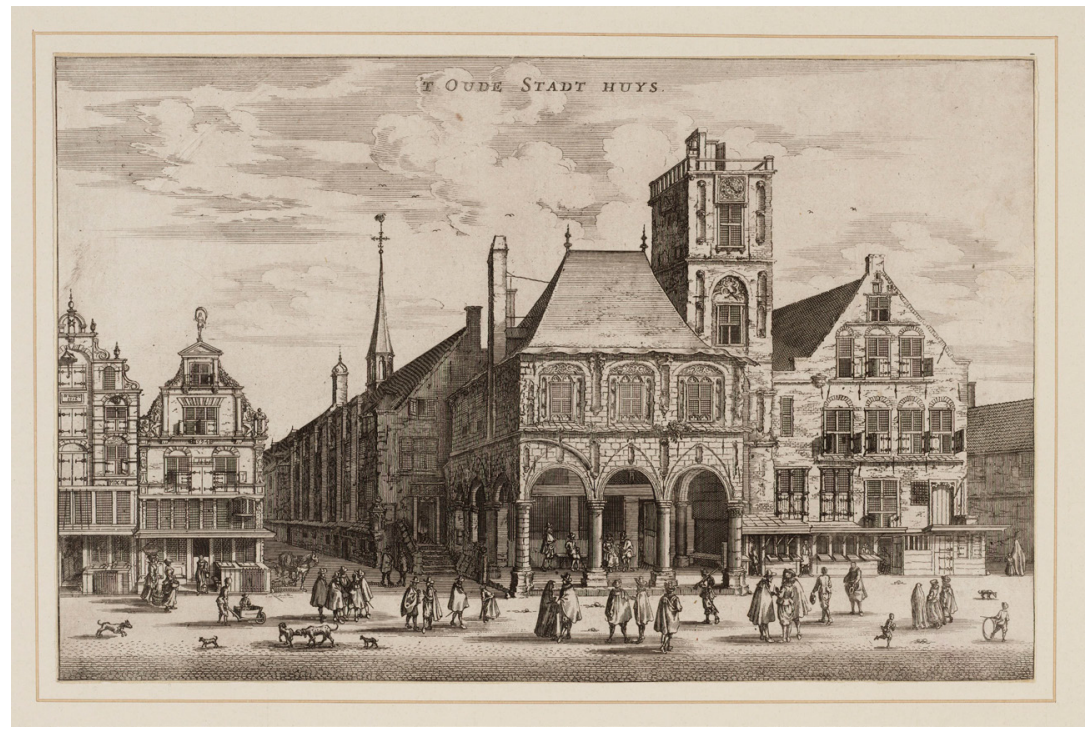

Illustration 3 This drawing depicts the old Amsterdam City Hall in the 1640s, now the location of Amsterdam's Royal Palace. The building was home to the Wisselbank, where international merchants were obliged to process their bills of exchange. This financial function has long fascinated financial historians, but research (inspired) by Joost revealed that the city hall also provided financial services to more ordinary burghers of Amsterdam. These services came about because the city hall was where the city's aldermen recorded mortgages and, secondly, because the municipal orphan masters - who managed the estates of underage orphans and provided loans from these estates - resided here (source: Amsterdam City Archive, Collection Atlas Splitgerber, entry number 10094).

Just as had happened in the case of the Gerschenkron paradigm, financial historians thus did what they do best with respect to the North-Weingast paradigm: set it aside, and investigate what actually happened. The varied sources and methods they employed again remind us that good financial history does not necessarily require narrow theoretical models and econometric tools. The analytic narratives favoured by Joost - that is, those inspired by economic theory and based on whatever sources are available - often work much better. ${ }^{69}$ The way Joost goes about writing these analytic narratives is what we turn to next.

republic', in: W.N. Goetzmann et al. (eds.), The great mirror of folly. Finance, culture, and the crash of 1720 (New Haven 2013) 121-140; R. Frehen, W. Goetzmann and G. Rouwenhorst, 'New evidence on the first financial bubble',Journal of FinancialEconomics 108(2013) 585-607. On Dutch investments in England from the late seventeenth century onwards, see: J.C. Riley, International government finance and the Amsterdam capital market 1 740-1815 (Cambridge 1980); C. van Bochove, The economic consequences of the Dutch. Economic integration around the NorthSea, $1500-1800$ (Amsterdam 2008); Carlos and Neal, 'Amsterdam', 21-46. 69 See, e.g., the work of his PhD students (supervized with M. 't Hart): Feenstra, Between shared and conflicting interests; and the forthcoming dissertations of Josje Schnitzeler on Holland's orphan cham- 


\section{Undertaking financial history}

Over the past quarter century, financial history has moved from the fringes of economic history to the very core of many of its debates. The reason is twofold. On the one hand, the scope of financial history research has broadened, turning away from the narrow study of banks and towards discovering the broad variety of financial institutions used by governments, businesses, and households throughout history. On the other hand, there are much better data now, for example, on corporate forms, fiscal revenues, stock prices, and public and private interest rates. These data have turned national financial histories into attractive laboratories for testing modern theories of, for example, corporate finance, asset pricing, and market micro-structure..$^{70}$

The definitive move of financial history to the centre ground of finance and economics research came with the financial crisis of 20072008. Booms and busts were a long-standing subject of academic enquiry for financial historians, particularly the role of the central bank in precipitating or rescuing banks from failure. ${ }^{71}$ The Global Financial Crisis stimulated further work on banking crises,${ }^{72}$ but with the whole system on the verge of a complete breakdown (which very few people saw coming) there was a new and very strong demand, both within the

bers, Laura van Hasselt on C.P. van Eeghen, and Paul Koulen on plantation loans in Essequibo, Demerary, and Berbice.

70 For a discussion related to ours, see: E. Monnet and F.R. Velde, 'Money, banking, and old-school historical economics', in: A. Bisin and G. Federico (eds.), The handbook of historical economics (London 2021) $335^{-3} 64$.

71 The classic account remains: C.P. Kindleberger, Manias, panics, and crashes. A history offinancial crises (London 1978), now in its seventh edition (2015). See also: P. Temin, Lessons from the Great Depression (Cambridge MA 1989); B.J. Eichengreen, Golden fetters. The gold standard and the Great Depression, 191 9-1939 (New York 1992); P.M. Garber, Famous first bubbles. The fundamentals of early manias (Cambridge MA 2000). For Joost's own contributions on this topic, see: J. Jonker, and J.L. van Zanden, 'Method in the madness? Banking crises between the wars, an international comparison', in: C.H. Feinstein (ed.), Banking, currency, and finance in Europe between the Wars (Oxford 1995); and J. Jonker, 'Between private responsibility and public duty. The origins of bank monitoring in the Netherlands, 186o-1930', Financial History Review 3 (1996) 139-152.

72 Much of this literature concerned the interwar period. See, e.g.: M. Carlson and K.J. Mitchener, 'Branch banking as a device for discipline. Competition and bank survivorship during the Great Depression', Journal of Political Economy 11:2 (2009) 165-210; P. Hansen, 'Making sense of financial crisis and scandal. A Danish bank failure in the first era of finance capitalism', Enterprise \& Society 13 (2012) 672-706; J. Turner, Banking in crisis. The rise and fall of British banking stability, 1800 to the Present (Cambridge 2014); Petram, The world's first stock exchange; N. Postel-Vinay, 'What caused Chicago bank failures in the Great Depression? A look at the 1920s', The Journal of Economic History 76:2 (2016) 478-519. For the Netherlands, see: Colvin et al., 'Predicting the past'. 
economics profession and beyond, to find out what went wrong. ${ }^{73} \mathrm{Fi}$ nancial historians answered the call with monographs that looked at historical parallels and precedents to the most recent crisis, and they offered insightful accounts of the development of financial systems as a whole. Take, for example, the work of Larry Neal detailing the interaction between public and private finance from the seventeenth century onwards, identification by Hoffman et al. of the role of the middle class in the emergence of financial intermediation, or Jeffrey Frieden's probing analysis of the interaction between financial development and globalization. ${ }^{74}$

It is noteworthy that many historical studies that appeared after the crisis broke in 2007 were the result of years of research conducted before the crisis. The crisis, then, provided an opportunity to recast research in light of current events; financial historians offered in-depth comparative analyses, as in the studies by Charles Calomiris and Stephen Haber and by John Turner on the political economy of banking and finance, or Barry Eichengreen's work on the Great Recession and the Great Depression. ${ }^{75}$ Through a careful comparison of national financial histories across time and space, they were able to show the balance of power between the government and the financial sector differs strongly between countries, which has profound consequences for the incidence of banking crises and the overall contribution of financial institutions to economic growth and development. ${ }^{76}$ These studies have gained financial historians a much wider audience for their work and, with so much damage done to the lives of ordinary people, have resulted in far fewer doubts about the relevance of financial history research.

73 C.L. Colvin and P. Winfree, 'Applied history, applied economics, and economic history', Journal of Applied History 1:1-2 (2019) 28-41.

74 Neal, 'How it all began'. Cf also his book: A concise history of international finance. From Babylon to Bernanke (Cambridge 2015). J.A. Frieden, Global capitalism. Its fall and rise in the twentieth century (New York 2006); P.T. Hoffman, G. Postel-Vinay and J.-L. Rosenthal, Surviving large losses. Financial crises, the middle class, and the development of capital markets (Cambridge MA 2009). See also the work by Avner Offer and Monica Prasad on the interaction between financial development and the rise of the welfare state: M. Prasad, The land of too much. American abundance and the paradox of poverty (Cambridge MA 2012); A. Offer, 'The market turn. From social democracy to market liberalism', The Economic History Review $70: 4$ (2017) 1051-1071.

75 Calomiris and Haber, Fragile by design; Turner, Banking in crisis; B. Eichengreen, Hall of mirrors. The Great Depression, the Great Recession, and the uses - and misuses - of history (New York 2015).

76 For a similar approach, see: R.S. Grossman, Unsettled account. The evolution of banking in the industrialized world since 1800 (Princeton 2010); Y. Cassis, Crises and opportunities. The shaping of modern finance (Oxford 2011). 
The work of financial historians has also become more valuable in a very practical sense. Take, for example, Reinhart and Rogoff's widely cited This Time is Different. ${ }^{77}$ Leaving aside the 'Excel Error' that undermined one of their main conclusions, their analysis would have been unthinkable without the work of two generations of financial historians on financial crises and public debt. ${ }^{7}$ And yet, the ever-stronger empirical basis of financial history research may pose a new threat to the discipline. For some economists do not really care about the past per se, but merely exploit history as a methodology with which to address issues of causality. ${ }^{79}$ While the use of econometrics has greatly increased our understanding of, for example, the finance/growth nexus, ${ }^{80}$ or the dynamics of international capital flows, ${ }^{81}$ it can also lead to a narrow use of history to generate 'stylized facts' that are then invoked to motivate clever arguments about plausibly exogenous variation. A prominent example has been presenting past legal systems as determinants of present-day outcomes, and using this relationship to inform a discussion on the optimal design of financial systems. ${ }^{82}$ While constituting a conceptually interesting exercise, such work has proved to be largely ahistorical. It has taken a decade's worth of work by financial historians studying how business owners actually organized their firms to undo the damage and prove the stylized facts to be stylized fictions. ${ }^{8_{3}}$

It goes without saying that writing financial history necessitates causal reasoning, which requires either explicit or implicit use of theory. However, much of the economics profession now also believes that

77 C.M. Reinhart and K.S. Rogoff, This time is different. Eight centuries of financial folly (Princeton 2009).

78 On the 'Excel Error': T. Herndon, M. Ash and R. Pollin, 'Does high public debt consistently stifle economic growth? A critique of Reinhart and Rogoff', Cambridge Journal of Economics 38:2 (2014) 257279. For a broader perspective on the verification and replication of economics research: G. Christensen and E. Miguel, 'Transparency, reproducibility, and the credibility of economics research', Journal of Economic Literature 56:3 (2018) 920-980.

79 R. Morck and B. Yeung, 'Economics, history, and causation', The Business History Review 85:1 (2011) $39-63$.

8o See, e.g.: R. Levine, 'Financial development and economic growth. Views and agenda', Journal of Economic Literature 35:2 (1997) 688-726; Rousseau and Sylla, 'Financial systems', 373-416.

81 The classic study is: Neal, The rise. For a recent example: P. Koudijs, 'The boats that did not sail. Asset price volatility in a natural experiment', Journal of Finance 71:3 (2016) 1185-1226, who exploited the way in which information flowed between London and Amsterdam in the eighteenth century to test various hypothesized explanations on short-term stock price fluctuations.

82 R. La Porta et al., 'Law and finance', Journal of Political Economy 106:6 (1998) 113-115.

83 See the various responses to La Porta et al. by financial historians reviewed in: A. Musacchio and J.D. Turner, 'Does the law and finance hypothesis pass the test of history?', Business History 55:4 (2013) 524-542. 
'legitimate' causal stories must make use of a limited set of what are known as 'causal inference methodologies', such as quasi-experimental verification using instrumental variables or difference-in-differences. While additions to this genre have been very interesting and have genuinely contributed to important questions in financial economics, from the perspective of financial historians this choice looks rather limiting. ${ }^{84}$ For a start it would mean we cannot research contexts where these methods are unsuited - because either the (numerical) evidence is unavailable - or where (plausible) exogeneity cannot be established. Privileging these causal inference methodologies as the sole route to knowledge about causal processes also leads to a very narrow understanding of the concept of causality itself - one that ultimately strips away the causal reasoning, removes the economic theory. Essentially, knowledge is generated only from those limited research settings in which a subset of empirical methods can be used to satisfy certain statistical conditions. This process excludes most historical settings. It is also not very good economics, in that we often do not learn very much about the underlying causal chain in these natural experiments; the exact mechanism linking cause and effect remains a 'black box'.

We think financial historians have more to offer, and Joost's work provides a perfect illustration. His various contributions to understanding the origins and early development of Dutch sovereign debt, or his enquiries into the myriad ways in which trade and industry were financed in nineteenth-century the Netherlands, are all examples of analytic narratives - 'thick descriptions' that combine textured and sequenced accounts with logical reasoning from economics. ${ }^{85}$ They may seem excessively descriptive to some readers, but economic theory provides the framing, the classification scheme that helps to organize and systematize the evidence into something useful. To that end, the role of the financial historian is to uncover archival evidence and use this in conjunction with the relevant theory to write empirically sound narratives that link cause and effect.

84 For exceptions that utilize historical variation in an economic analysis, while still dealing sensitively with the substance of the history, see especially: P. Koudijs and L. Salisbury, 'Limited liability and investment. Evidence from changes in marital property laws in the US South, 1840-1850', Journal of Financial Economics 138:1 (2020) 1-26; P. Koudijs, L. Salisbury and G. Sran, 'For richer, for poorer. Bankers' liability and bank risk in New England, 1867 to 1880', The Journal of Finance 76:3 (2021) 1541-1599. 85 Cf. A. de Jong, D.M. Higgins and H. van Driel, 'Towards a new business history?', Business History 57:1 (2015) 5-29: a call to action that urged business historians to move beyond biographical accounts of big businesses. 
Robert Merton's six financial functions is one such economic theory. ${ }^{86}$ His perspective on financial intermediation is best understood by contrasting it with the alternative, more pervasive, institutional perspective. As the name suggests, an institutional perspective starts with the institutions (or, more accurately perhaps, the organizations) that provide financial services and then asks: what services do they serve and for whom? The functional perspective turns the sequence on its head and starts with the services or functions themselves rather than the institutions that provide them. As a theory, Merton's functional perspective describes well what financial professionals also practice; the creation of complex financial institutions as new ways to achieve the same old financial functions led directly to the financial crisis that started in 2007-2008. ${ }^{87}$ Joost identified that the functional perspective provides a powerful conceptual framework for the analysis of financial systems in the past. ${ }^{88}$ In short, Merton's descriptive taxonomy is perfectly suited to more backward-looking enquiry, which does not run the risk of causing another global financial crisis!

What Joost and his collaborators have shown using the analytic narratives approach is that there are other ways of writing causal stories, ones that put causal reasoning back into the mix and make use of other methodologies and evidential bases. In practice, this process is about putting the historical method more explicitly back into how we write financial history. By historical method, we mean the collection and assessment of diverse types of historical sources produced by actors contemporaneous to the events as they unfold. These sources can be qualitative or quantitative. Such evidence may be only partial; it is the role of the historian to piece together disparate sources and make a plausible judgement. Economic theory, then, guides this judgement. Economic theory helps financial historians answer the question: what is the plausible causal story, given the evidence available?

86 R.C. Merton, 'A functional perspective of financial intermediation', Financial Management 24:2 (1995) 23-41; R.C. Merton and Z. Bodie, 'A conceptual framework for analyzing the financial environment', in: D.B. Crane et al. (eds.), The global financial system. A functional perspective (Boston 1995) 3-31. 87 And, as a foreshadowing of that crisis, the failure of Merton's own long-term capital management venture. See description in: M. de Goede, 'Discourses of scientific finance and the failure of Long-Term Capital Management', New Political Economy 6:2 (2001) 149-170.

88 For an explicit use of these functions in Joost's work, see:Jonker, 'Competing in tandem'; O. Gelderblom, J. Jonker and C. Kool, 'Direct finance in the Dutch Golden Age', The Economic History Review 69:4 (2016) 1178-1198; O. Gelderblom, M. Hup and J. Jonker, 'Public functions, private markets. Credit registration by aldermen and notaries in the Low Countries, 1500-180o', in: Lorenzini, Lorandini, and Coffman (eds.), Financing in Europe, 163-194. 
The first step in Joost's research roadmap is to (temporarily) set aside what we think we know about financial history. Then he goes about writing a new description, from the ground up, by piecing together archival sources. Only once this is completed is Joost ready to return to the dominant narratives and see how his new narrative fits. At this point, existing explanations may need to be adapted or entirely abandoned. To achieve this feat, Joost employs the skillset of a social science historian: he makes a judgement, based on the balance of probability using all available evidence, about what is the most likely explanation for the phenomenon under scrutiny. This process is abductive, in contrast to the more inductive approach of the historian or the deductive approach of the economist. Joost's way of undertaking financial history is not about testing hypotheses generated by economic theory. Nor is economic theory totally absent from his work: it fulfils an altogether different purpose. The theory is there to categorize and classify his findings, to locate his narratives in the wider universe of financial histories. $^{89}$

\section{Contemplating the future of financial history}

So what will be next in financial history research? When Joost entered the field in the late 1980s, debates revolved around a few big ideas. As time went by, the foundational work of financial historians who had simply been 'following the money' proved instrumental in revising some of these bigger ideas, simply by pointing out what actually happened. We cannot predict which big ideas will carry away economic historians in the years to come. Within the field Joost has worked in, though, we can identify some undercurrents of high-quality empirical work that will likely help us to deepen our understanding of economic history from the late medieval period onwards.

A first trend we observe is that of financial historians embracing the functional perspective pioneered by Joost. It is most apparent in new work that is coming out on Europe before the Industrial Revolution. The outward appearance of these earlier financial systems is often so different from what we see in the world today that we have to look for similarities (or differences) in function, not form. Thus we find early modernists exploring the ways in which investors managed and

89 For a recent example, see: A. de Jong et al., 'Repurposing institutions. Trust offices and the Dutch financial system, 169os-20oos', Enterprise \& Society (2021). 
priced risks,${ }^{90}$ organized payments and loans, ${ }^{91}$ pooled resources,${ }^{92}$ and worked their way around information asymmetries..$^{93}$ Admittedly, there remains a strong desire among these scholars to identify forerunners or early examples of modern institutions, but the actual research they do reveals, for example, how financial systems function in medieval grain milling in southern France, in the silver and copper mines of Central Europe, the iron and coal mines of seventeenth-century Liège, and in trade, transport, and insurance in eighteenth-century England. ${ }^{94}$

This 'functional turn' can forge stronger ties between the work of financial historians and others. Consider what is arguably the most inaccessible, technical, and inward-looking of all financial history topics: the organization of payments. Once the exclusive domain of numismatists, this field has opened up to social and cultural historians, to political economists, and to modern finance scholars. ${ }^{95}$ For example, Kuroda and Zelizer have demonstrated how money should be understood in its social context, and scholars like Vickers and Lucassen have familiar-

90 A.L. Murphy, 'Trading options before Black-Scholes. A study of the market in late seventeenth-century London', The Economic History Review 62:1 (2009) 8-30. In insurance markets: J. Puttevils and M. Deloof, 'Marketing and pricing risk in marine insurance in sixteenth-century Antwerp', The Journal of Economic History 77:3 (2017) 796-837; O. Gelderblom, A. de Jong and J. Jonker, 'Learning how to manage risk by hedging. The VOC insurance contract of 1613', European Review of Economic History 24:2 (2020) 332-355. In private debt markets: C. van Bochove and T. van Velzen, 'Loans to salaried employees. The case of the Dutch East India Company, 1602-1794', European Review of Economic History 18:1 (2014) 19-38. In public debt markets: C. Chamley, 'Interest reductions in the politico-financial nexus of eighteenth-century England', The Journal of Economic History 71:3 (2011) 555-589; Cf. also Velde and Weir, 'The financial market'.

91 J. Puttevils, Merchants and trading in the sixteenth century. The Golden Age of Antwerp (London 2015); V.A. Santarosa, 'Financing long-distance trade. The joint liability rule and bills of exchange in eighteenth-century France', The Journal of Economic History 75:3 (2015) 690-719.

92 D. De ruysscher, 'Naer het Romeinsch Recht alsmede den stiel mercantiel'. Handel en recht in de Antwerpse rechtbank (16 de-1 7 de eeuw) (Kortrijk 2009); B. Van Hofstraeten, 'The organization of mercantile capitalism in the Low Countries private partnerships in early modern Antwerp (1480-1620), TSEG - The Low Countries Journal of Social and Economic History 13:2 (2016) 1-24.

93 Koudijs, 'The boats'.

94 D. le Bris, W.N. Goetzmann and S. Pouget, 'The present value relation over six centuries. The case of the Bazacle company', Journal of Financial Economics 132:1 (2019) 248-265; S. Jenks, 'The first bubble. Silver mining in the Saxon Erzgebirge, c.1470-1540', Mimeo, University of Erlangen (2010); B. Van Hofstraeten, 'Delving for diversity in early modern company law. Mining companies in seventeenthcentury Liège', in D. De ruysscher et al., (eds.), The company in law and practice. Did size matter? (Middle ages-nineteenth century) (Leiden 2017) 84-109; R. Harris, Industrializing English law. Entrepreneurship and business organization, 1720-1844 (Cambridge 2000).

95 J. Lucassen and J. Zuijderduijn, 'Coins, currencies, and credit instruments. Media of exchange in economic and social history', TSEG - The Low Countries Journal of Social and Economic History 11:3 (2014) 1-13. 
ized social and cultural historians with this new view on money. ${ }^{96}$ Asking very basic questions about the different types of coin people used to make payments, Sargent and Velde unravelled the technical and political requirements for the production of stable coins, Boerner and Volckart provided an early, fifteenth-century example of a stable currency union that facilitated payments between people living in different polities, and Quinn and Roberds have shown how the local government of a leading commercial city - Amsterdam - were able to devise monetary instruments and policies that created a stable international payment system..$^{97}$

Second, besides a steady flow of work on specific financial intermediaries, there is a growing body of work that focusses on the demand for, rather than the supply of, financial services. Among early modernists, this reorientation began with historians who found that their main source for research into material culture - probate inventories - also held very valuable information on people's financial behaviour. ${ }^{98}$ In much the same way, financial historians of the eighteenth and nineteenth centuries discovered inheritance tax returns - which have been typically used to document wealth inequality - also contained detailed information on investment in public and private securities, short- and

96 V.A. Zelizer, The social meaning of money. Pin money, paychecks, poor relief, and other currencies (Princeton 2017); A. Kuroda, 'Concurrent but non-integrable currency circuits. Complementary relationships among monies in modern China and other regions', Financial History Review 15 (2008) 17-36; Vickers, 'Errors expected', 1032-1057; J.M.W.G. Lucassen, 'Deep monetization, the case of the Netherlands', TSEG - The Low Countries Journal of Social and Economic History 11:3 (2014) 73-121; S. Felten, The social life of money in the Dutch Republic. Everyday practice and circuits of exchange (forthcoming). Joost's contributions to this field: T. Kooijmans and J. Jonker, 'Chained to the manor? Payment patterns and landlord-tenant relations in the Salland region of the Netherlands around 1750', TSEG - The Low CountriesJournal of Social and Economic History, 12:4 (2015) 89-116; O. Gelderblom and J.Jonker, 'Enter the ghost. Cashless payments in the early modern Low Countries, 1500-180o' in: R.J. van der Spek and B. van Leeuwen (eds.), Money, currency and crisis. In search of trust, 2000 BC to AD 2000 (London 2018) 240-247.

97 T.J. Sargent and F.R. Velde, The big problem of small change (Princeton 2002); L. Boerner and O. Volckart, "The utility of a common coinage. Currency unions and the integration of money markets in late Medieval Central Europe', Explorations in Economic History 48:1 (2011) 53-65; S. Quinn and W. Roberds, 'How Amsterdam got fiat money',Journal of Monetary Economics 66 (2014), 1-12; S, Quinn and W. Roberds, 'Responding to a shadow banking crisis. The lessons of 1763', Journal of Money, Credit and Banking 47:6 (2015) 1149-1176.

98 McCants, 'Goods at pawn'; T. Lambrecht, 'Rural credit and the market for annuities in eighteenthcentury Flanders', in: Lambrecht and Schofield (eds.), Credit and the rural economy, 75-98; B. Willems, Leven op de pof. Krediet bij de Antwerpse middenstand in de achttiende eeuw (Amsterdam 2009); Ogilvie, Küpker and Maegraith, 'Household debt'; H. Deneweth and P. Wallis, 'Households, consumption and the development of medical care in the Netherlands, 1650-1900', Journal of Social History 49:3 (2016) 532-557; Dermineur, 'Peer-to-peer lending', 359-388. 
long-term credit, the penetration of banks and other intermediaries, and the persistence of peer-to-peer lending alongside financial institutions. ${ }^{99}$

Research on stock market investments is often framed as an inquiry into the origins of modern portfolio management, including the emergence of mutual funds and investment trusts. ${ }^{100}$ However, there is a growing interest in the actual decision making of private investors and the self-help books, advertisements, and personal experience on which their decisions were based. ${ }^{101}$ In the Netherlands, the first mutual funds had very limited success, maturing as institutions only late in the twentieth century. ${ }^{102}$ Through the work of Joost, we know Dutch investors instead engaged with the stock market through a much more diverse group of intermediaries, including local commission traders, directly with stock brokers, and even via so-called administratiekantoren. ${ }^{103}$ The day-to-day functioning of these overlapping institutions is something that has yet to be fully understood. Indeed, the history of the Amsterdam Stock Exchange, its associated institutions, and its customers will be the subject of a major new project at the University of Groningen, on which Joost will serve in an advisory capacity.

The shift in focus from supply to demand is perhaps less pronounced in the history of banking and insurance in the twentieth century, but there are clear signs this situation is about to change. Recent work on savings banks in the US and Germany explicitly questions the role they

99 L. Di Matteo, 'The determinants of wealth and asset holding in nineteenth-century Canada. Evidence from microdata', The Journal of Economic History 57:4 (1997) 907-934; H. Lindgren, 'The modernization of Swedish credit markets, 1840-1905: Evidence from probate records', The Journal of Economic History 62:3 (2002) 810-832; L. Di Matteo and A. Redish, 'The evolution of financial intermediation. Evidence from 19th-century Ontario microdata', Canadian Journal of Economics 48:3 (2015) 963-987. 100 For a review, see: Turner, 'Financial history'.

101 J. Rutterford and D.P. Sotiropoulos, 'Financial diversification before modern portfolio theory. UK financial advice documents in the late nineteenth and the beginning of the twentieth century', The European Journal of the History of Economic Thought 23:6 (2016) 919-945; P. Crosthwaite, P. Knight and N. Marsh, 'The economic humanities and the history of financial advice', American Literary History 31:4 (2019) 661-686.

102 K.G. Rouwenhorst, 'Structured finance and the origins of mutual funds in 18th-century Netherlands', in: D. Chambers and E. Dimson (eds.), Financialmarket history. Reflections on the past for investors today (London 2016) 207-226; B. Slot, Iedereen kapitalist. De ontwikkeling van het beleggingsfonds in Nederland gedurende de 2oste Eeuw (Amsterdam 2005). Cf. for an (unsuccessful) early attempt to attract investors to the Belgium stock market: J. Annaert and G. Verdickt, 'Go active or stay passive. Investment trust, financial innovation and diversification in Belgium's early days', Explorations in Economic History $79(2021) 101378$.

103 De Jong et al., 'Repurposing institutions'. 
played in the financial strategies of households, ${ }^{104}$ and there is a growing literature on the major transformation of payment systems that accompanied the rise of retail banking. ${ }^{105}$ As for research on consumer credit, US and UK historians are firmly in the lead with innovative empirical work on payday loans, instalment credit, mutual insurance, and credit rating. ${ }^{106}$ One explanation for this trend is the early expansion of consumer credit in these countries, but interest in the topic also stems from the fact that in the US and the UK today many poor households have turned away from commercial banks. ${ }^{107}$ Which brings us to the final question we think will guide future work on financial history: the dynamics of inclusive finance.

Banking for the 'unbanked and underbanked' is the area where demand-led functional approaches to financial history have already become prominent. Tracing the extension of savings and loans in the nineteenth and early twentieth centuries to small rural and urban customers harks back to Joost's earliest publications, on Dutch Raiffeisen banks. ${ }^{108}$ Combined with the information economics popularized in the work of Guinnane, Joost's students and colleagues have continued

104 S. Lehmann-Hasemeyer and J. Streb, 'Does social security crowd out private savings? The case of Bismarck's system of social insurance', European Review of Economic History 22:3 (2018) 298-321; S. Sprick Schuster, M. Jaremski and E.R. Perlman, 'An empirical history of the US postal savings system', Social Science History 44:4 (2020) 667-696.

105 B. Bátiz-Lazo, Cash and dash. How ATMs and computers changed banking (Oxford 2018).

106 On consumer credit: M.L. Olney, Buy now, pay later. Advertising, credit, and consumer durables in the 1920 (Chapel Hill 1991); L. Calder, Financing the American dream. A cultural history of consumer credit (Princeton 1999); R.-M. Gelpi and F. Julien-Labruyère, The history of consumer credit. Doctrines and practices (Basingstoke 2000); L. Hyman, Debtor nation. The history of America in red ink (Princeton 2011); J. Logemann (ed.), The development of consumer credit in global perspective. Business, regulation, and culture (New York 2012). On payday loans: J.P. Caskey, Fringe banking. Check-cashing outlets, pawnshops, and the poor (New York 1994); M. Easterly, 'Your job is your credit. Creating a market for loans to salaried employees in New York City, 1885-1920', Enterprise \& Society 10 (2009) 651-66o. On insurance: J. Levy, Freaks of fortune. The emerging world of capitalism and risk in America (Cambridge MA 2014). On credit rating: J. Lauer, Creditworthy a history of consumer surveillance and financial identity in America (New York 2017). See also, for England: S. O'Connell, Credit and community. Working-class debt in the UK since 1880 (Oxford 2009); for France: S. Effosse, Le crédit à la consommation en France, 1947-1 965: de la stigmatisation à la réglementation. (Paris 2014); T. van der Valk, Household finance in France and the Netherlands 1960-2000. An evolutionary approach, unpublished PhD dissertation (Utrecht University 2019).

107 M. Baradaran, How the other half banks. Exclusion, exploitation, and the threat to democracy (Cambridge MA 2015); L. Servon, The unbanking of America. How the new middle class survives (Boston 2017). Cf. also, for a historical exploration of the unbanked: R.E. Wright, Financial exclusion. How competition can fix a broken system (Great Barrington 2019).

108 Jonker, 'Welbegrepen eigenbelang'; Idem, 'Boerenvreugde of boerenverdriet?'. 
to look at the Netherlands' rural cooperatives, ${ }^{109}$ while also broadening this outlook to urban cooperatives ${ }^{110}$ and other types of loan societies typically overlooked in financial histories because of their small scale. ${ }^{111}$ Joost's own update to this topic, with Heidi Deneweth and Oscar Gelderblom, maps out the whole ecosystem of financial services in the nineteenth-century Netherlands and explicitly relates them to ideas about modern microfinance. ${ }^{12}$ Scholars of other countries have followed suit. ${ }^{113}$

As anyone who knows Joost will appreciate, he cherishes two distinct approaches to financial history and the future of finance. There is 'Joost the pragmatist', who poses questions about the nature of financial services as they are or have been. He asks questions like: how does a central bank conduct its work as supervisor? ${ }^{114}$ Or: are banks the cost-efficient service providers they claim to be? ${ }^{115}$ Yet there is also 'Joost the idealist', who has a clear vision of what the world ought to look like. This Joost asks questions like: why did the Dutch government allow Curaçao to become a tax haven? ${ }^{116}$ And: does the financial sector live up

109 C.L. Colvin and E. McLaughlin, 'Raiffeisenism abroad. Why did German cooperative banking fail in Ireland but prosper in the Netherlands?', The Economic History Review 67:2 (2014), 492-516; C.L. Colvin, 'Banking on a religious divide. Accounting for the success of the Netherlands' raiffeisen cooperatives in the crisis of the 1920s', The Journal of Economic History 77:3 (2017), 866-919; C.L. Colvin, S. Henderson and J.D. Turner, 'The origins of the (cooperative) species. Raiffeisen banking in the Netherlands, 1898 1909', European Review of Economic History 24:4 (2020) 749-782.

110 C.L. Colvin, 'Organizational determinants of bank resilience. Explaining the performance of SME banks in the Dutch financial crisis of the 1920s', Business History Review 92:4 (2018) 661-69o; R. Peeters, 'Getting a foot in the door. Small-firm credit and interest group politics in the Netherlands, 1900-1927', Enterprise \& Society (2020).

111 A. de Vicq and C. van Bochove, 'Historical diversity in financial intermediation. Co-signatory lending institutions in Europe and North America, 170os-196os', Mimeo, Utrecht University (2021).

112 H. Deneweth, O. Gelderblom and J.Jonker, 'Microfinance and the decline of poverty. Evidence from the nineteenth-century Netherlands', Journal of Economic Development 39:1 (2014) 79-110. Joost also studied the broadening access to consumer credit in: J. Jonker, M. Milo and J. Vannerom, 'From hapless victims of desire to responsibly choosing citizens. The emancipation of consumers in Low Countries' consumer credit regulation', BMGN - Low Countries Historical Review 132:3 (2017) 115-138. On the latter, see: P. van Dam, 'Tales of the market. New perspectives on consumer society in the 2oth century', $H$ Soz-Kult 04.12.2015 (www.hsozkult.de/literaturereview/id/forschungsberichte-2832).

113 For example, for the case of Ireland, see: E. McLaughlin, "Profligacy in the encouragement of thrift". Savings banks in Ireland, 1817-1914', Business History 56:4 (2014) 569-591.

114 Jonker, 'Between private responsibility'.

115 J. Jonker, 'Grösse um jeden Preis, der Aufstieg und der vorhersehbare Fall von ABN AMRO 196o2006', H. Wixforth (ed.), Geld und Kapital, Jahrbuch der Gesellschaft für mitteleuropäische Banken- und Sparkassengeschichte (Stuttgart 2010) 175-198.

116 T. van Beurden and J. Jonker, 'A perfect symbiosis. Curaçao, the Netherlands and financial offshore services, 1951-2013', Financial History Review 28:1 (2021) 67-95. Also see: V. Ogle, “Funk money”. The 
to its promise to act in a socially responsible way? ${ }^{117}$ It is his passionate pursuit of both approaches that makes reading Joost's work so rewarding.

\section{About the authors}

Christiaan van Bochove was until recently Assistant Professor of Economic, Social and Demographic History at Radboud University, and is now Associate Professor of Economic and Social History at Utrecht University. Email: c.j.vanbochove@uu.nl.

Christopher L. Colvin is Senior Lecturer in Economics at Queen's University Belfast, where he co-directs the university's Centre for Economic History. Email: chris.colvin@qub.ac.uk.

Oscar Gelderblom is Professor of Financial History at Utrecht University, and will soon be Professor of Financial History at the University of Antwerp.

Email: o.gelderblom@uu.nl.

\section{Appendices}

\section{Working with Joost Jonker}

In recent years university leaders and academic policy-makers have come to realize something is amiss with the way we evaluate the performance of scholars. ${ }^{118}$ The ubiquitous practice of gauging research quality using narrow metrics - such as publication counts, impact factors, citation scores, and grant sizes - ignores the many other contributions scholars make to science and society. Yet university administrators struggle to find better ways to recognize and reward academics.

end of empires, the expansion of tax havens, and decolonization as an economic and financial event', Past \& Present 249:1 (2020) 213-249.

117 J. Jonker, 'Introduction', in: A. Cantaluppi et al., Social aims offinance. Rediscovering varieties of credit in financial archives (Frankfurt am Main 2020) 11-20.

118 Cf. the 2019 policy paper of the Young Academy (DJA), the Royal Netherlands Academy of Arts and Sciences (KNAW), the Dutch Research Council (NWO) and The Netherlands Organization for Health Research and Development (ZonMw), and the Association of Universities in the Netherlands (VSNU), 'Room for everyone's talent. Towards a new balance in the recognition and rewards of academics'. 
We think the way forward is to watch and learn from the way in which scholars actually develop their research agendas, conduct interdisciplinary work, produce open data, engage with non-academic audiences, and offer academic training.

Joost is an unlikely role model. Starting out as a research assistant and ending his career as a professor, Joost's academic career progression appears rather conventional. Even so, appearances can be deceiving. Joost achieved each step in a way that is against the grain and not typically valued as highly in our profession - at least, not in recent decades. Although he was frequently involved in major grant proposals in the fields of business and financial history, he never acted as a project's frontman, as its principal investigator. Instead, he took a more modest role behind the scenes, driving these projects by identifying the interesting research questions and communicating their societal relevance.

Joost is also not a likely role model in terms of his approach to interdisciplinary research. While he continued to place a lot of importance on reconstructing the past by crafting carefully-researched historical narratives, the mainstream of our profession was instead turning towards a more 'scientific' approach, with hypotheses, econometrics, and quantification galore. Yet, again, appearances can be deceiving. Particularly in the most recent decade of his career, Joost has engaged closely with approaches to history from other disciplines, including legal analysis and more quantitative methodologies. While these approaches are always components his co-authors and students bring to the table, it is clear from talking to these collaborators why they wanted Joost on their team: his deep historical knowledge and insight, combined with his unparalleled ability to frame research questions and write up research findings as beautiful prose, always makes his contribution invaluable. The lesson for university leaders is stark: if they want interdisciplinarity, then they have to ensure that there is the best possible training available within each separate discipline. There are limits to scholars who are 'jacks of all trades'; the true benefit of research collaboration comes from specialization.

The importance of teamwork brings us to Joost's services to the profession and his public engagement. Here, too, Joost was often at odds with the mainstream of his profession. For every public lecture, podcast, or op-ed article to his name, there is also an editorial board, programme committee, or historical consultation where he delivered behind-thescenes assistance. Often his assistance concerns thorny societal issues, is delivered behind closed doors, and without gaining any public ac- 
knowledgement. And then there are the projects that simply would not have got off the ground without Joost's involvement: the computer simulation of seventeenth-century merchant Amsterdam (The Game of the Golden Age), the official history of Royal Dutch/Shell, and, most recently, the open-source publication of historical stock prices of the world's oldest exchange.

The same goes for Joost's contribution to teaching and learning. There, too, his impact is not immediately evident. While Joost has taught many courses in Utrecht and Amsterdam, he was never a lecturer who played to mass audiences, designed new programmes, or engaged with new methods of e-learning. Instead, it is Joost's role as a mentor to researchers which sets him apart. He has provided invaluable assistance to both his own students and to many others by engaging with them in person, offering bespoke advice, reading and commenting on their work, and coming up with practical solutions to their problems - and always with a warm concern for the person behind the research.

It is particularly Joost's skill as a fantastic writer that brings countless researchers to his door. He always offers his mentorship freely, not just to his own students but also to countless other junior researchers, and not just in his own fields of financial and business history but also to researchers in cultural and legal history, as well as in economics and finance - not to mention the guidance he regularly gives to international scholars making visits to Dutch archives. Indeed, it is his role as a mentor that his various more or less senior scholars may be taken aback by. For his interactions with colleagues in his own institutions and in his own fields of research are not always the easiest. His judgement of their work can be very cutting, and being on the receiving end of his commentary is not always pleasant. Joost has a strong independent streak and is often quite stubborn, refusing to consider an explanation without very strong evidence. We know this from personal experience.

Nevertheless, you have to set this against Joost's other characteristics: principally, his selflessness and his generosity, his willingness to help without expecting any personal gain. Joost has been the invisible $\mathrm{x}$-factor behind the success of countless papers, $\mathrm{PhD}$ manuscripts, monographs, research proposals, and knowledge exchanges. And he will no doubt continue to provide his unique modus operandi well into his formal retirement. 
Bibliography of scholarly works (until 2021 )

While including all of Joost Jonker's academic publications to date that we are aware of, this list excludes his other writings (such as op-ed articles and book reviews).

2021

with Tijn van Beurden, 'A perfect symbiosis. Curaçao, the Netherlands and financial offshore services, 1951-2013', Financial History Review 28:1 (2021) 67-95.

with Abe de Jong, Ailsa Röell and Gerarda Westerhuis, 'Repurposing institutions. Trust offices and the Dutch financial system, 169os-20oos', Enterprise \& Society (2021).

2019

'Klem tussen de lokale en mondiale markt. De Amsterdamse Haute Banque vanaf het midden van de zestiende tot het begin van de twintigste eeuw (deel 1, 1550-1763)', Amstelodamum 106:1 (2019) $25-45$.

'Klem tussen de lokale en mondiale markt. De Amsterdamse Haute Banque vanaf het midden van de zestiende tot het begin van de twintigste eeuw (deel 2, 1763-1914)', Amstelodamum 106:2 (2019) $63-87$.

'Introduction', in: Anna Cantaluppi, Chloe Colchester, Lilia Costabile, Carmen Hofmann, Catherine Schenk and Matthias Weber (eds.), The social aims of finance. Rediscovering varieties of credit in financial archives (Frankfurt am Main 2O2O) 11-2O.

with Oscar Gelderblom and Abe de Jong, 'Learning how to manage risk by hedging. The VOC insurance contract of 1613', European Review of Economic History 24:2 (2020) 332-355.

2018

'Hoboken, Anthony van', in: Biografisch woordenboek van Nederland (http://resources.huygens.knaw.nl/bwn1780-1830/lemmata/data/ hoboken).

'Hope, Henry', in: Biografisch woordenboek van Nederland (http:// resources.huygens.knaw.nl/bwn1780-1830/lemmata/data/hope). with Oscar Gelderblom, 'Enter the ghost. Cashless payments in the early modern Low Countries, 1500-180o', in: R.J. van der Spek and B. 
van Leeuwen (eds.), Money, currency and crisis. In search of trust, 2000 BC to $A D 2000$ (Abingdon 2018) 224-247.

with Oscar Gelderblom, 'Rentes, tontines, actions', in: Catherine Secretan and Willem Frijhoff (eds.), Dictionnaire des Pays-Bas au Siècle d'or (Paris 2018) 622-623.

with Oscar Gelderblom and Mark Hup, 'Public functions, private markets. Credit registration by aldermen and notaries in the Low Countries, 1500-1800', in: Marcella Lorenzini, Cinzia Lorandini and D'Maris Coffman (eds.), Financing in Europe. Evolution, coexistence and complementarity of lending practices from the middle ages to modern times (Cham 2018) 163-194.

2017

'Macht der gewoonte. Verzonnen tradities in de vroege Nederlandse vrijmetselarij', Thoth 68 (2017) 6-21.

with Peter van Dam, 'Introduction. The rise of consumer society', $B M G N$ - Low Countries Historical Review 132:3 (2017) 3-10.

with Giuseppe Dari-Mattiacci, Oscar Gelderblom and Enrico Perotti, 'The emergence of the corporate form', The Journal of Law, Economics, and Organization 33:2 (2017) 193-236.

with Michael Milo and Johan Vannerom, 'From hapless victims of desire to responsibly choosing citizens. The emancipation of consumers in Low Countries consumer credit regulation', BMGN - Low Countries Historical Review 132:3 (2017), 115-138.

2016

'Creative destruction and regeneration of cities', in:Virginie Mamadouh and Anne Wageningen (eds.), Urban Europe. Fifty tales of the city (Amsterdam 2016) 162-170.

with Oscar Gelderblom, 'Financiële zelfredzaamheid in Nederland sinds 1750', Economisch Statistische Berichten 101:4731 (2016) 244247.

with Oscar Gelderblom and Clemens Kool, 'Direct finance in the Dutch Golden Age', The Economic History Review 69:4 (2016) 11 78-1198.

2015

'Creatieve vernietiging en herstel van steden', in: Virginie Mamadouh and Anne van Wageningen (eds.), EU@ Amsterdam: Een Stedelijke Raad. Essays over de Europese stad (Amsterdam 2015) 165-170. 
'Kroeller, Anthony George (1862-1941), in: Biografisch woordenboek van Nederland (http://resources.huygens.knaw.nl/bwn188o-200o/ lemmata/bwn6/kroeller)'.

with Tim Kooijmans, 'Chained to the Manor? Payment patterns and landlord-tenant relations in the Salland region of the Netherlands around 1750', Tijdschrift voor Sociale en Economische Geschiedenis 12:4 (2015) 89-115.

2014

'The Netherlands and the polder model - Nederland en het poldermodel', BMGN - Low Countries Historical Review 129:1 (2014) 88-89.

'The power of the past. Inventing traditions in early Amsterdam freemasonry', Journal for Research into Freemasonry and Fraternalism 5:2 (2014) 135-153.

'Velde, Johanna Jacoba van de, in: Digitaal vrouwenlexicon van Nederland (http://resources.huygens.knaw.nl/vrouwenlexicon/lemmata/ data/Borski,\%2oJohanna)'.

with Heidi Deneweth and Oscar Gelderblom, 'Microfinance and the decline of poverty. Evidence from the nineteenth-century Netherlands', Journal of Economic Development 39:1 (2014) 79-110.

with Oscar Gelderblom, 'The Low Countries', in: Larry Neal and Jeffrey G. Williamson (eds.), The Cambridge history of capitalism I: The rise of capitalism. From ancient origins to 1848 (Cambridge 2014) 314356 .

2013

'De Amsterdamse economie, 1850-1950', in: Matthijs Dicke and A. van der Zouwen (eds.), Nederlandse ondernemers 1850-1950 V: Amsterdam (Amsterdam 2013) 24-29.

'Crena de Iongh, Daniël (1888-1970)', in: Biografisch woordenboek van Nederland (http://resources.huygens.knaw.nl/bwn1880-200o/ lemmata/bwn $5 /$ crena).

'Heijn, Albert (1865-1945)', in: Biografisch woordenboek van Nederland (http://resources.huygens.knaw.nl/bwn188o-20oo/lemmata/ bwn6/heijn).

'Hengel, Adrianus Johannes van (1886-1936)', in: Biografisch woordenboek van Nederland (http://resources.huygens.knaw.nl/bwn188o200o/lemmata/bwn6/hengel). 
'Mannheimer, Fritz (189o-1939)', in: Biografisch woordenboek van Nederland (http://resources.huygens.knaw.nl/bwn188o-200o/lemmata/bwn $5 /$ mannheimer).

with O. Gelderblom, 'Low Countries finance, 1348-1700', in: Gerard Caprio Jr. (ed.), Handbook of key global financial markets, institutions, and infrastructure (Oxford 2013) 175-183.

with Oscar Gelderblom, 'Mirroring different follies. The character of the 1720 bubble in the Dutch republic', in: William N. Goetzmann, Catherine Labio, K. Geert Rouwenhorst and Timothy G. Young (eds.), The great mirror of folly. Finance, culture, and the crash of 1720 (New Haven 2013) 121-140.

with Oscar Gelderblom and Abe de Jong, "The formative years of the modern corporation. The Dutch East India Company VOC, 16021623', The Journal of Economic History 73:4 (2013) 1050-1076.

with Abe de Jong and Ailsa Röell, 'De ontwikkeling van de naamloze vennootschap in Nederland tot $185^{\circ}$. Een bedrijfseconomisch perspectief', Maandblad voor Accountancy en Bedrijfseconomie 87 (2013) 217-232.

with A. de Jong and A. Röell, 'Dutch corporate finance, 1602-1850', in: Gerard Caprio Jr. (ed.), Handbook of key global financial markets, institutions, and infrastructure (Oxford 2013) 73-83.

'Aller ogen gericht op...? De relevantie van de bedrijfsgeschiedenis', Oratiereeks Universiteit van Amsterdam 453 (2012).

with Ruben Schalk and Oscar Gelderblom, 'Schipperen op de Aziatische vaart. De financiering van de VOC kamer Enkhuizen, 16021622', BMGN-Low Countries Historical Review 127:4 (2012) 3-27.

2011

with Oscar Gelderblom, 'Public finance and economic growth. The case of Holland in the seventeenth century', The Journal of Economic History 71:1 (2011) 1-39.

with Oscar Gelderblom and Abe de Jong, 'An admiralty for Asia. Business organization and the evolution of corporate governance in the Dutch Republic, 1590-1640', in: Jonathan G.S. Koppell (ed.), Origins of shareholder advocacy (New York 2011) 29-6o. 
'Größe um jeden Preis. Der Aufstieg und der vorhersehbare Fall von ABN AMRO 196o-2006', in: Harald Wixforth (ed.), Geld und Kapital. Jahrbuch der Gesellschaft für mitteleuropäische Banken- und Sparkassengeschichte (Stuttgart 2010) 175-198.

2009

with Oscar Gelderblom, 'With a view to hold. The emergence of institutional investors on the Amsterdam securities market during the seventeenth and eighteenth centuries', in: Jeremy Atack and Larry Neal (eds.), The origins and development of financial markets and institutions. From the seventeenth century to the present. (Cambridge 2009) 71-98.

2008

'Comments from an early modern and modern perspective', in: Peter Spufford, How rarely did medieval merchants use coin? (Utrecht 2008) 59-63.

with Keetie Sluyterman and Jan Luiten van Zanden, “Koninklijke” en haar aandeelhouders, 189o-2005', in: Wim Boonstra and Sylvester Eijffinger (eds.), Een klassiek econoom met een brede blik. Opstellen aangeboden aan Hans Visser (The Hague 2008) 295-308.

2007

with Stephen Howarth, A history of Royal Dutch Shell II: Powering the hydrocarbon revolution, 1939-1973 (Oxford 2007).

with Stephen Howarth, Geschiedenis van Koninklijke Shell II: Stuwmotor van de koolwaterstofrevolutie, 1933-1973 (Amsterdam 2007).

with Jan Luiten van Zanden, A history of Royal Dutch Shell I: From challenger to joint industry leader, $1890-1939$ (Oxford 2007).

with Jan Luiten van Zanden, Geschiedenis van Koninklijke Shell I: Van nieuwkomer tot marktleider, 1890-1939 (Amsterdam 2007).

with Jan Luiten van Zanden, 'Searching for oil at Roubaix', The Rothschild Archive. Review of the Year April 2006 to March 2007 (2007) 21-25. 
with Oscar Gelderblom 'Amsterdam as the cradle of modern futures and options trading, 1550-1650', in: William N. Goetzmann and K. Geert Rouwenhorst (eds.), The origins of value. The financial innovations that created modern capital markets (Oxford 2005) 189-205.

2004

with Oscar Gelderblom, 'Completing a financial revolution. The finance of the Dutch East India trade and the rise of the Amsterdam capital market, 1595-1612', The Journal of Economic History 64:3 (2004) 641-672.

2003

'Competing in tandem. Securities markets and commercial banking patterns in Europe during the nineteenth century', in: Douglas J. Forsyth and Daniel Verdier (eds.), The origins of national financial systems. Alexander Gerschenkron reconsidered (London 2003) 64-86.

2002

'De vroege geschiedenis van de firma Insinger \& Co', Jaarboek Amstelodamum 94 (2002) 110-131.

with Ton de Graaf and Jaap-Jan Mobron (eds.), European banking overseas, 19th-2oth century (Amsterdam 2002).

2000

with Keetie Sluyterman, At home on the world markets. Dutch international trading companies from the 16 th century until the present (The Hague 2000).

with Keetie Sluyterman, Thuis op de wereldmarkt. Nederlandse handelshuizen door de eeuwen heen (The Hague 2000).

1999

'Geld-en bankwezen, 1815-199o', in: Ronald van der Bie and Pit Dehing (eds.), Nationaal goed. Feiten en cijfers over onze samenleving (ca.)1800-1999 (Amsterdam 1999) 61-72.

'The cradle of modern banking. Finance in the Netherlands between the Napoleonic era and the first commercial banks, 1813-1870', in: Joh. de Vries, Wim Vroom and Ton de Graaf (eds.), Worldwide banking. ABN AMRO Bank 1824-1999 (Amsterdam 1999) 49-94. 
'De bakermat van het moderne bankwezen. De Nederlandse geldhandel tussen Franse Tijd en de eerste handelsbanken 1813-187o', in: Joh. de Vries, Wim Vroom and Ton de Graaf (eds.), Wereldwijd bankieren. ABNAMRO 1824-1 999 (Amsterdam 1999) 49-94.

with Keetie E. Sluyterman, 'The lure of industry. Dutch trading companies entering and abandoning industrial activities', in: Franco Amatori, Andrea Colli and Nicola Crepas (eds.), Deindustrialization and reindustrialization in 2oth century Europe (Milan 1999) 372-382.

1997

MeesPierson. Schakel tussen verleden en toekomst. 275 Jaar traditie en vernieuwing in het Nederlandse bankwezen (Amsterdam 1997).

'The alternative road to modernity. Banking and currency, 1814-1914', in: Marjolein 't Hart, Joost Jonker and Jan Luiten van Zanden (eds.), A financial history of the Netherlands (Cambridge 1997) 94-123. with Marjolein 't Hart and Jan Luiten van Zanden (eds.), A financial history of the Netherlands (Cambridge 1997).

1996

Merchants, bankers, middlemen. The Amsterdam money market during the first half of the 19 th century (Amsterdam 1996).

'Between private responsibility and public duty. The origins of bank monitoring in the Netherlands, 186o-1930', Financial History Review 3:2 (1996) 139-152.

1995

'Spoilt for choice? Banking concentration and the structure of the Dutch banking market, 1900-1940', in: Youssef Cassis, Gerald D. Feldman and Ulf Olsson (eds.), The evolution of financial institutions and markets in twentieth-century Europe (Aldershot 1995) 187-208. with Jan Luiten van Zanden, 'Method in the madness? Banking crises between the wars, an international comparison', in: Charles H. Feinstein (ed.), Banking, currency, and finance in Europe between the wars (Oxford 1995) 77-93.

1994

'In het middelpunt en toch aan de rand. Joodse bankiers en effectenhandelaren, 1815-1940', in: Hetty Berg, Thera Wijsenbeek and Eric Fischer (eds.), Venter, fabriqueur, fabrikant. Joodse ondernemers en ondernemingen in Nederland 1796-1940 (Amsterdam 1994) 92-113. 
1992

'Kassierspapier', in: Jan Lucassen (ed.) Gids van de papiergeld-verzameling van het Nederlandsch Economisch-Historisch Archief (Amsterdam 1992) 107-120.

with Bob de Graaff, The optimum formula for a foreign policy document series. Proceedings of the second conference of editors of diplomatic documents, The Hague 16 and 17 January 1992 (The Hague 1992).

1991

'Lachspiegel van de vooruitgang. Het historiografische beeld van de Nederlandse industriefinanciering in de negentiende eeuw', $\mathrm{NE}$ HA-Bulletin 5:1 (1991) 3-24.

'Sinecures or sinews of power? Interlocking directorships and bank-industry relations in the Netherlands, 1910-1940', Economic and Social History in the Netherlands 3 (1991) 119-132.

1990

with A.E. Kersten and G.N. van der Plaat (eds.), Vijftig jaar na de inval. Geschiedschrijving en Tweede Wereldoorlog. Bijdragen aan het congres gehouden aan de Vrije Universiteit te Amsterdam op 10 en $11 \mathrm{mei}$ 1990 (The Hague 1990).

1989

'Waterdragers van het kapitalisme. Nevenfuncties van Nederlandse bankiers en de verhouding tussen bankwezen en bedrijfsleven, 1910-1940', Jaarboek voor de Geschiedenis van Bedrijf en Techniek 6 (1989) 158-19o.

1988

'Boerenvreugde of boerenverdriet? De NCB en de emancipatie van het Brabantse platteland, 1896-1920', Tijdschrift voor Sociale Geschiedenis 14 (1988) 444-490.

'Welbegrepen eigenbelang. Ontstaan en werkwijze van boerenleenbanken in Noord-Brabant, 1900-1920', Jaarboek voor de Geschiedenis van Bedrïf en Techniek 5 (1988) 188-207. 